\title{
Anti-cancer and anti-inflammatory effects elicited by short chain fatty acids produced by Escherichia coli isolated from healthy human gut microbiota
}

\author{
Atchareeya Nakkarach ${ }^{1,2}$, Hooi Ling Foo ${ }^{1,3^{*}}$ (D) Adelene Ai-Lian Song ${ }^{3,4}$, Nur Elina Abdul Mutalib5, \\ Sunee Nitisinprasert ${ }^{2}$ and Ulaiwan Withayagiat ${ }^{2,6^{*}}$
}

\begin{abstract}
Background: Extracellular metabolites of short chain fatty acids (SCFA) excreted by gut microbiota have been reported to play an important role in the regulation of intestinal homeostasis. Apart from supplying energy, SCFA also elicit immune stimulation in animal and human cells. Therefore, an attempt was conducted to isolate SCFA producing bacteria from healthy human microbiota. The anti-cancer and anti-inflammatory effects of extracellular metabolites and individual SFCA were further investigated by using breast, colon cancer and macrophage cells. Toxin, inflammatory and anti-inflammatory cytokine gene expressions were investigated by RT-qPCR analyses in this study.
\end{abstract}

Results: Escherichia coli KUB-36 was selected in this study since it has the capability to produce seven SCFA extracellularly. It produced acetic acid as the main SCFA. It is a non-exotoxin producer and hence, it is a safe gut microbiota. The $\mathrm{IC}_{50}$ values indicated that the E. coli KUB-36 metabolites treatment elicited more potent cytotoxicity effect on MCF7 breast cancer cell as compared to colon cancer and leukemia cancer cells but exhibited little cytotoxic effects on normal breast cell. Furthermore, E. coli KUB-36 metabolites and individual SCFA could affect inflammatory responses in lipopolysaccharide-induced THP-1 macrophage cells since they suppressed inflammatory cytokines IL-1 $\beta$, IL-6, IL-8 and TNF- $a$ well as compared to the control, whilst inducing anti-inflammatory cytokine IL-10 expression.

Conclusion: SCFA producing E. coli KUB-36 possessed vast potential as a beneficial gut microbe since it is a nonexotoxin producer that exhibited beneficial cytotoxic effects on cancer cells and elicited anti-inflammatory activity simultaneously. However, the probiotic characteristic of E. coli KUB-36 should be further elucidated using in vivo animal models.

Keywords: Anti-cancer, Anti-inflammatory, Cytokines, Escherichia coli, Short chain fatty acid

*Correspondence: fagiulw@ku.ac.th; hlfoo@upm.edu.my

${ }^{3}$ Institute of Bioscience, Universiti Putra Malaysia, 43400 UPM Serdang, Selangor, Malaysia

${ }^{6}$ Fermentation Technology Research Center, Faculty of Agro-Industry, Kasetsart University, Chatuchak 10900, Bangkok, Thailand

Full list of author information is available at the end of the article

\section{Background}

Gut microbiota is a large and diverse group of microorganisms that live in the gastrointestinal tract. The human gut contains approximately $10^{14}$ microorganisms, which play an important role in gut homeostasis which impact host metabolism, health and disease $[1,2]$. One of the important metabolites that is produced by gut microbiota is short chain fatty acid (SCFA). The major SCFA

c) The Author(s) 2021. This article is licensed under a Creative Commons Attribution 4.0 International License, which permits use, sharing, adaptation, distribution and reproduction in any medium or format, as long as you give appropriate credit to the original author(s) and the source, provide a link to the Creative Commons licence, and indicate if changes were made. The images or other third party material in this article are included in the article's Creative Commons licence, unless indicated otherwise in a credit line to the material. If material is not included in the article's Creative Commons licence and your intended use is not permitted by statutory regulation or exceeds the permitted use, you will need to obtain permission directly from the copyright holder. To view a copy of this licence, visit http://creativeco mmons.org/licenses/by/4.0/. The Creative Commons Public Domain Dedication waiver (http://creativecommons.org/publicdomain/ zero/1.0/) applies to the data made available in this article, unless otherwise stated in a credit line to the data. 
are acetic, butyric and propionic ( $\geq 95 \%)$ acids, whereas formic, valeric, caproic acids, etc., make up the remaining SCFA [3], whereby they reduce the luminal $\mathrm{pH}$, enhance the absorption of some nutrients and have direct impact on the gut microbiota composition [4]. Moreover, SCFA are the main energy source for colon cells. It has been demonstrated that $70 \%$ of energy obtained by intestinal epithelial cells is derived from butyric acid, which is mainly produced by commensal bacteria, especially from the Firmicutes phyla such as Ruminococcus and Faecalibacterium [5]. However, Escherichia coli Nissle 1917, a Gram-negative bacterium that has been reported to be a probiotic bacterium also produces SCFA as the end products of carbohydrate metabolism under anaerobic growth condition, with mainly acetic acid and some propionic and butyric acids [6].

SCFA has been shown to have an impact on the immune system, which can reduce the risk of inflammatory diseases, type 2 diabetes, obesity, heart disease and other symptoms including cancer [7]. Chronic inflammation induces persistent damage and plays a role in the development of cancer [8]. Cancer is a leading cause of death worldwide, especially breast cancer and colorectal cancer [9]. Nowadays, chemoprevention is considered generally as a better means than the therapeutic approach. Probiotic supplement has been used as biotherapeutic and have been reported to have anti-cancer effect [10], whereby the beneficial effects of probiotic bacteria have been regarded to be mediated by their extracellular metabolites of SCFA.

Moreover, SCFA have been demonstrated to modulate the production of inflammatory mediators by macrophages. SCFA, especially butyric acid, suppress the productions of lipopolysaccharide (LPS), nitric oxide (NO) and common cytokines such as tumor necrosis factor $\alpha$ (TNF- $\alpha$ ), interleukins 6 and 8 (IL-6, and IL-8), which are known to induce inflammatory responses. In addition, SCFA also enhance the expression of anti-inflammatory cytokine such as Interleukins (IL-10) [11-16]. Faecalibacterium prausnitzii is the first anti-inflammatory commensal bacteria that was identified based on human clinical data and it is one of the major butyric acid-producer of the human intestinal microbiota [17, 18]. However, other gut microbiota such as Bifidobacterium and Lactobacillus species have been reported to exhibit anti-inflammatory property [19-22], along with E. coli Nissle 1917, which is a commensal bacterium with defect in its LPS biosynthesis and hence it is accepted and used as a probiotic strain for the treatment of inflammatory gastrointestinal diseases [23]. Interestingly, Tsilingiri et al. [24] has proposed the utilisation of postbiotic metabolites produced by the probiotic Lactobacillus sp. as a safe alternative for the treatment of patients with inflammatory bowel disease in the acute inflammatory phase. Subsequently, prominent probiotic effects of bacteriocin-containing postbiotic metabolites produced by six strains of Lactobacillus plantarum have been documented extensively for rats [25-27], poultry [28, 29], pigs [30] and lambs [31]. The L. plantarum strains produce several postbiotic metabolites such as lactic acid, acetic acid [32, 33] and bacteriocin [34, 35]. Recently, postbiotic metabolites produced by the six strains of $L$. plantarum have been shown to elicit selective cytotoxic effect and induction of apoptosis via a strain-specific and cancer cell type-specific manner whilst sparing the normal cells [36]. Therefore, the postbiotic metabolites of L. plantarum were suggested as a functional supplement and as an adjunctive treatment for cancer.

In the present study, an attempt was conducted to characterize the SCFA produced by a beneficial, Escherichia coli KUB-36 that was isolated from healthy human gut microbiota. The anti-cancer effects of the SCFA-consisting metabolite of $E$. coli KUB-36 were subsequently determined by using normal cell line, breast cancer cell line, colon cancer cell line and leukemia cancer cell line. Moreover, the anti-inflammatory effect of the $E$. coli KUB-36 metabolite were elucidated under inflammatory condition using a gene expression approach. The individual SCFA that produced by E. coli KUB-36 were also investigated simultaneously to characterize the main SCFA that elicited the anti-cancer and anti-inflammatory activities.

\section{Results \\ Isolation and characterization of SCFA producing gut microbiota}

A total of 294 bacterial cultures were isolated from 3 feces samples of healthy Thai adults. The acid producing bacteria was then screened preliminarily by a change of color in bromothymol blue dye. The extracellular SCFA profile of 185 acid producing bacteria isolates were distinguished subsequently by gas chromatography. The highest butyric acid producing bacteria were selected for phenotypic and genotypic identification and characterization (Fig. 1). The morphological observation via Gram staining showed that the isolated bacteria was a Gramnegative and rod shaped bacterial. It was then designated as E. coli KUB-36 since the alignment of the $16 \mathrm{~S}$ rRNA gene demonstrated more than $99 \%$ sequence similarity to the NCBI deposited 16S rRNA genes of E. coli strains (results not shown). The threshold of $98.7 \%$ similarity for 16S rRNA genes is essential for species identification [37]. To confirm the potential health benefits as a probiotic bacterium, E. coli KUB-36 was subsequently elucidated for anti-inflammatory and anti-cancer properties. 


\section{Toxin genes detection}

Lipopolysaccharide (LPS) is a large molecule found on the outer membrane of Gram-negative bacteria that generally elicits strong immune response in humans and animals. Hence, the presence of 10 LPS endotoxin genes and two exotoxin genes in E. coli KUB-36 were determined by PCR in this study using specific primers that were designed based on the conserved regions analysed by multiple alignments of DNA sequences deposited in the NCBI database. Table 1 shows the primer sequences and toxin gene profiles detected for E. coli KUB-36. The results showed that $E$. coli KUB-36 was positive for $l p x A, \operatorname{lp} x B, \operatorname{lp} x C, l p x D$, waaF and $w z y$ endotoxin genes, but negative for the waaC, waaL, waaQ, wzz endotoxin genes and both $e l t B$ and $s t b$ exotoxin genes. These results indicated that $E$. coli KUB-36 did not harbour endotoxin genes that responsible for LPS biosynthesis, hence, resulting in a defective LPS production in E. coli KUB-36.

\section{Short chain fatty acid profile}

E. coli KUB-36 was grown in Wilkins Chalgren broth at $37{ }^{\circ} \mathrm{C}$ for $24 \mathrm{~h}$ under anaerobic condition, whereby the SCFA were analysed at four-hour intervals by gas chromatography. Table 2 shows the SCFA concentrations produced by $E$. coli KUB-36. The highest SCFA was detected at $8 \mathrm{~h}$ of incubation time. Interestingly, the selected $E$. coli KUB-36 produced mainly acetic acid (23.89 mM), followed by caproic acid, butyric acid, valeric acid, isovaleric acid, propionic acid and iso-butyric acid with 3.63 , $3.01,2.83,2.78,2.15$ and $1.69 \mathrm{mM}$ respectively. Therefore, the concentrations of SCFA at $8 \mathrm{~h}$ of incubation was used for subsequent study.

\section{Cytotoxic effect of E. coli KUB-36 metabolite and individual SCFA on Cancer Cells}

Generally, MTT assay was used to determine the cytotoxicity, viability and proliferation of living cells. In this study, the concentration that inhibit $50 \%$ growth $\left(\mathrm{IC}_{50}\right)$ of MCF10A normal breast cell, MCF7 breast cancer cell, HT-29 colon cancer cell and THP-1 leukaemia cancer cell was determined for 24, 48 and $72 \mathrm{~h}$ of incubation to compare the cytotoxicity effects of E. coli KUB-36 metabolites and individual SCFA that produced by $E$. coli KUB-36.

For MCF10A normal breast cell, the $\mathrm{IC}_{50}$ value of the $E$. coli KUB-36 metabolites were $75.96 \%, 68.49 \%$ and $64.39 \%$ of the original concentration for 24, 48 and $72 \mathrm{~h}$ of incubation respectively, which were the lowest cytotoxicity activity as compared to all individual SCFA that were present in the E. coli KUB-36 metabolites, indicating that the E. coli KUB-36 metabolites has very limited cytotoxicity against the normal MCF10A breast cell. Nevertheless, acetic acid has exerted the highest cytotoxicity activity on MCF10A breast cell (Fig. 2a) as compared to all individual SCFA that present in the E. coli KUB-36 metabolites.

In comparison, MCF7 breast cancer cells have demonstrated a reverse trend of cytotoxicity activity, whereby the E. coli KUB-36 metabolites elicited more significant cytotoxicity as compared to other individual SCFA with the $\mathrm{IC}_{50}$ value of $48.84 \%, 37.99 \%$ and 43.79 of the original concentration detected at 24,48 and $72 \mathrm{~h}$ of incubation respectively. Surprisingly, acetic acid also exerted a similar cytotoxicity effect on MCF7 breast cancer cell as shown in Fig. $2 b$.

For HT-29 colon cancer cell, the E. coli KUB-36 metabolites have exerted an $\mathrm{IC}_{50}$ value of $58.19 \%$, $55.31 \%$ and $50.68 \%$ of the original concentration respectively for 24,48 and $72 \mathrm{~h}$ of incubation. However, the acetic acid and butyric acid exerted better cytotoxicity activity as compared to E. coli KUB-36 metabolites. In addition, significant cytotoxicity activity was detected for 48 and $72 \mathrm{~h}$ of incubation for acetic acid, butyric, valeric and isovaleric acids as shown in Fig. 2c.

As for the THP-1 leukaemia cancer cell, the lowest cytotoxicity activities were detected for E. coli KUB36 metabolites and the individual SCFA as compared to other cell lines, whereby an $\mathrm{IC}_{50}$ value of $68.90 \%$, $57.54 \%$ and $51.98 \%$ of the original concentration were detected for 24, 48 and $72 \mathrm{~h}$ of incubation respectively for $E$. coli KUB-36 metabolites, suggesting that the $E$. coli KUB-36 metabolites and the individual SCFA that produced by $E$. coli KUB-36 have very little cytotoxicity against leukaemia cells as shown in Fig. 2d.

Interestingly, the $\mathrm{IC}_{50}$ value of various cancer cell lines indicated that the E. coli KUB-36 metabolites treatment elicited more potent cytotoxicity effect on MCF7 breast cancer cell as compared to colon cancer cell and THP-1 leukaemia cancer cell. Moreover, Fig. 3 shows that the cytotoxicity effect of $E$. coli KUB-36 cell-free supernatant on colon cancer cell was not significantly different at 24 , 48 and $72 \mathrm{~h}$. In contrast, the cytotoxicity effect at 24 and $72 \mathrm{~h}$ was significantly different for THP-1 leukaemia cancer cells.

\section{Nitric oxide production and cytokine gene expression of LPS stimulated THP-1 macrophage cell}

LPS is a major component of the outer membrane of Gram-negative bacteria that induces strong immune responses and plays a key role in inflammatory activities. In addition, nitric oxide (NO) is an important pro-inflammatory mediator produced by inducible NO synthase 


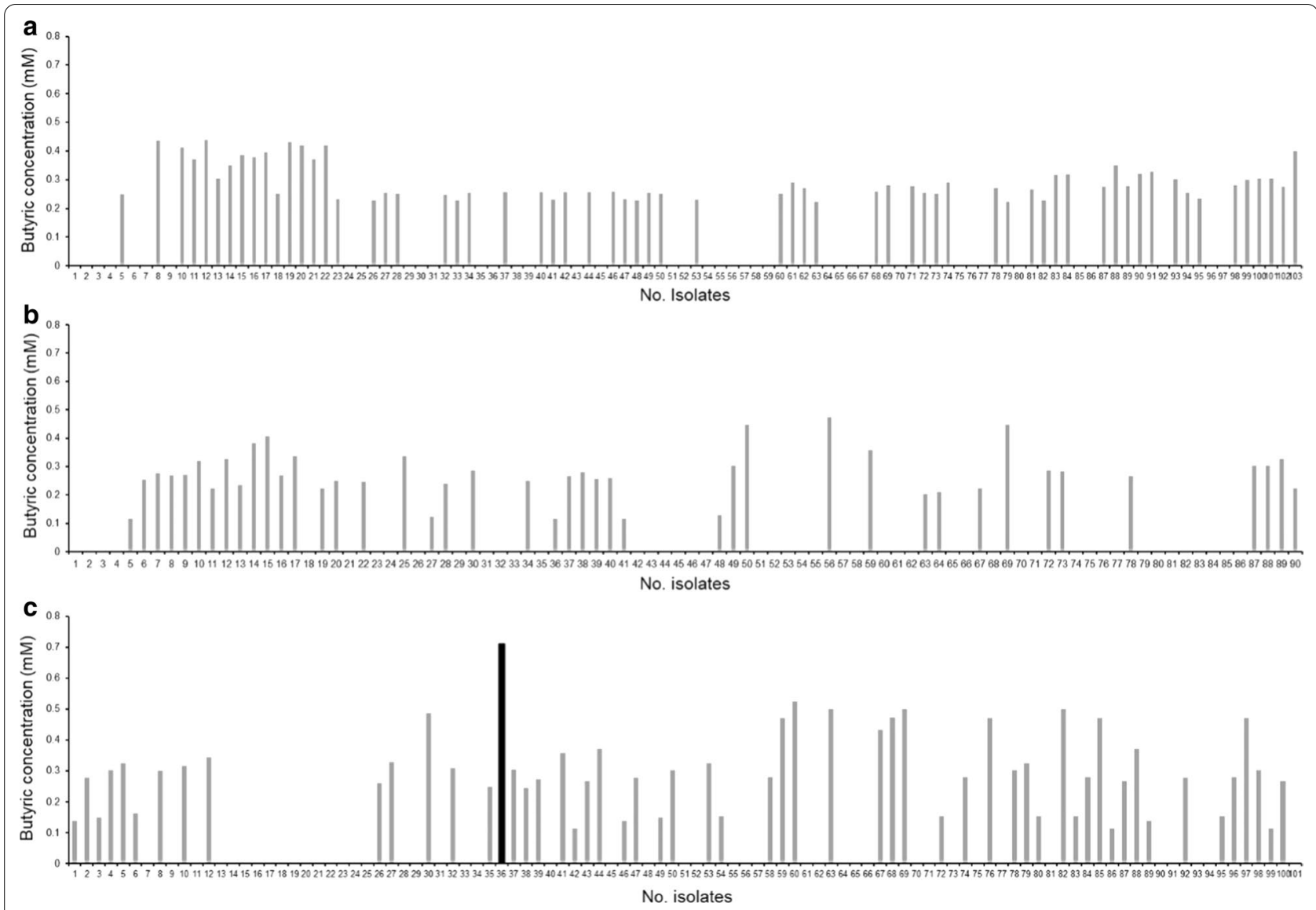

Fig. 1 Butyric acid concentration of 294 bacterial isolated from 3 heathy human faeces. a Butyric acid concentration of 103 bacteria isolated from faecal sample 1. b Butyric acid concentration of 90 bacteria isolated from faecal sample 2 and $\mathbf{c}$ butyric acid concentration of 101 bacteria isolated from faecal sample 3. Black bar chart represents bacterial isolate producing the highest butyric acid

and cyclooxygenase-2 (COX-2). Moreover, the cytokine genes IL-8, IL-1 $\beta$, IL-6, TNF- $\alpha$ and IL-10 are the regulators of pro- and anti-inflammatory immune responses. Therefore, the nitric oxide production and cytokine gene expression of THP-1 macrophage cells stimulated with control LPS and LPS of E. coli KUB-36 were investigated in this study as shown in Fig. 4. The results of NO production revealed that the highest NO production by THP-1 macrophage cells was stimulated by the control LPS as compared to the LPS of E. coli KUB-36, which was not significantly different from the non-stimulated THP-1 macrophage cells. This suggests that the LPS of E. coli KUB-36 did not induce any immune response and hence it did not have effect on inflammatory stimulation. The cytokine gene expressions of THP-1 macrophage cells stimulated by control LPS and LPS of E. coli KUB36 were analysed by qPCR as shown in Fig. 5 . The results showed that the expressions of cytokine IL-8, IL-1 $\beta$, IL-6 and TNF- $\alpha$ were induced substantially by the control LPS in comparison to LPS of E. coli KUB-36.
Effects of E. coli KUB-36 metabolites and individual SCFA on nitric oxide production and cytokine gene expression of LPS-stimulated THP-1 Macrophage cells

This study was conducted to investigate the inhibitory effect of E. coli KUB-36 metabolites and the individual SCFA on the production of NO by LPS-stimulated THP-1 macrophage cells. The level of NO production of LPS-stimulated THP-1 macrophage cells was determined by using a nitric oxide detection kit (iNtRON Biotechnology, Incheon, Korea). LPS-stimulation should up-regulate the NO production in THP-1 macrophage cells. However, Fig. 6 shows that the NO production of LPS-stimulated THP-1 macrophage cells was decreased after treatment with $E$. coli KUB-36 metabolites or individual SCFA. Generally, the NO production of E. coli KUB-36 metabolites treated of LPS-stimulated THP-1 macrophage cells was not significantly different from the NO production of individual SCFA treated of LPS-stimulated THP-1 macrophage cells, with the exception of acetic acid, where significant inhibitory effect was noted as 
Table 1 Endotoxin and exotoxin gene profiles of $E$. coli KUB-36

\begin{tabular}{|c|c|c|c|c|c|}
\hline \multirow[t]{2}{*}{ Toxin } & \multirow[t]{2}{*}{ Genes } & \multirow[t]{2}{*}{ Sequence } & \multirow{2}{*}{$\begin{array}{l}\text { Products Size } \\
\text { (bp) }\end{array}$} & \multicolumn{2}{|c|}{ Toxin gene detection } \\
\hline & & & & $\begin{array}{l}\text { E. coli } \\
\text { KUB-36 }\end{array}$ & $\begin{array}{l}\text { Pathogenic } \\
\text { E. coli }\end{array}$ \\
\hline \multirow[t]{20}{*}{ Endotoxin } & IpxA & 5'GATACGTGATTGATAAATCC3' & 799 & + & + \\
\hline & & 3'AGTCATTAACGAATCAGACC5' & & & \\
\hline & $\operatorname{lp} \times B$ & 5'CGTTAATGACTGAACAGCGT3' & 1159 & + & + \\
\hline & & 3'TTCGATCATTGTGCTAACTC5' & & & \\
\hline & $\operatorname{lpxC}$ & 5'ATACGATGATCAAACAAAGG3' & 928 & + & + \\
\hline & & 3'TGTCGTTATGCCAGTACAGC5' & & & \\
\hline & $\mid p \times D$ & 5'AAGTAATGCCTTCAATTCGA3' & 1036 & + & + \\
\hline & & 3'GAACGTTAGTCTTGTTGATT5' & & & \\
\hline & waac & 5'GACGGATGCGGGTTTTGATC3' & 970 & - & + \\
\hline & & 3'TACCTTTATAATGATGATAA5' & & & \\
\hline & waaF & 5'TCTGCATGAAAATACTGGTG & 1057 & + & + \\
\hline & & 3'ATCCGTCAGGCTTCCTCTTG5' & & & \\
\hline & waal & 5'AAAACATGCTAACATCCTTT3' & 1270 & - & + \\
\hline & & 3'TATTCTTAATTAATTGTATT5' & & & \\
\hline & waaQ & 5'CGGTGCTAGTATTAACACGT3' & 1043 & - & + \\
\hline & & 3'ATTTCTACGCTATAGTACCC5' & & & \\
\hline & wzy & 5'GTCGCATGAGTCTGCTGCAA3' & 1363 & + & + \\
\hline & & 3'CATTGTTATCCTTCAACCTG5' & & & \\
\hline & $w z z$ & 5'CTTTTCTAATGAAGCGCAAC3' & 988 & - & + \\
\hline & & 3'ATTACTACTCTCATCTTTTAA5' & & & \\
\hline \multirow[t]{4}{*}{ Enterotoxin } & $e t / B$ & 5'GTTGACATATATAACAGAATTCGGGATGAA3' & 604 & - & + \\
\hline & & 3'AAGCTTGCCCCTCCAGCCTAGCTTAGTTTT5' & & & \\
\hline & Stb & 5'TATTATATTTCGAAGCTTAAGTATTGTTGA3' & 1087 & - & + \\
\hline & & $3^{\prime}$ CATGACACGAAGCGCAGGCTGTTGCGCACC5' & & & \\
\hline
\end{tabular}

$+:$ present; - : not present

Table 2 Short chain fatty acid profiles produced by E. coli KUB-36

\begin{tabular}{|c|c|c|c|c|c|c|}
\hline \multirow[t]{2}{*}{ SCFA } & \multicolumn{6}{|c|}{ SCFA concentration (mM) } \\
\hline & $4 \mathrm{~h}$ & $8 \mathrm{~h}$ & $12 \mathrm{~h}$ & $16 \mathrm{~h}$ & $20 \mathrm{~h}$ & $24 \mathrm{~h}$ \\
\hline Acetic acid & $21.45 \pm 0.01^{d}$ & $23.89 \pm 0.12^{\mathrm{a}}$ & $23.47 \pm 0.44^{b}$ & $23.41 \pm 0.17^{b}$ & $22.26 \pm 0.34^{c}$ & $21.28 \pm 0.04^{e}$ \\
\hline Butyric acid & $1.53 \pm 0.04^{c}$ & $3.01 \pm 0.27^{\mathrm{a}}$ & $3.00 \pm 0.04^{\mathrm{a}}$ & $2.01 \pm 0.28^{b}$ & $1.46 \pm 0.26^{d}$ & $0.47 \pm 0.02^{e}$ \\
\hline Iso-butyric acid & $0.70 \pm 0.27^{c}$ & $1.69 \pm 0.22^{\mathrm{a}}$ & $1.66 \pm 0.07^{\mathrm{a}}$ & $0.84 \pm 0.47^{b}$ & $0.29 \pm 0.28^{d}$ & ND \\
\hline Propionic acid & $1.34 \pm 0.12^{c}$ & $2.15 \pm 0.31^{\mathrm{a}}$ & $2.13 \pm 0.29^{a}$ & $1.52 \pm 0.21^{b}$ & $1.36 \pm 0.17^{c}$ & $0.50 \pm 0.05^{d}$ \\
\hline Valeric acid & $1.70 \pm 0.13^{b}$ & $2.83 \pm 0.28^{\mathrm{a}}$ & $2.81 \pm 0.46^{\mathrm{a}}$ & $1.60 \pm 0.09^{b}$ & $0.86 \pm 0.03^{c}$ & $0.33 \pm 0.13^{d}$ \\
\hline Iso-valeric acid & $1.44 \pm 0.05^{b}$ & $2.78 \pm 0.13^{\mathrm{a}}$ & $2.71 \pm 0.02^{\mathrm{a}}$ & $1.44 \pm 0.07^{b}$ & $0.84 \pm 0.22^{c}$ & ND \\
\hline Caproic acid & $1.77 \pm 0.01^{d}$ & $3.63 \pm 0.18^{a}$ & $3.58 \pm 0.02^{b}$ & $2.02 \pm 0.04^{c}$ & $1.08 \pm 0.19^{e}$ & $0.56 \pm 0.20^{f}$ \\
\hline
\end{tabular}

Data are mean $\pm S D$ values calculated from three replicate

Different letters (a-f) in each row indicate a significant difference between means $(p<0.05)$. ND; non detected

compared to E. coli KUB-36 metabolite, butyric acid and caproic acid respectively.

Subsequently, the inhibitory effect of E. coli KUB36 metabolites and individual SCFA were investigated for the expression of inflammatory cytokines by the
LPS-stimulated THP-1 macrophage cells. Relative fold changes of 4 important inflammation-related gene expressions (cytokine IL-1 $\beta$, IL- 6 , IL- 8 and TNF- $\alpha$ ) that attributed to the LPS stimulation was used as a control for the inflammatory condition. Therefore, the level of 
cytokine gene expression that was above or below the control level was designated as inductive or suppressive inflammatory responses, respectively. Figure 7 shows the effect of E. coli KUB-36 metabolites and individual SCFA on cytokine gene (IL- $1 \beta$, IL- 6 , IL- 8 and TNF- $\alpha$ ) expressions of LPS-stimulated THP-1 macrophage cells. Interestingly, E. coli KUB-36 metabolites and its individual SCFA resulted in more than $80 \%$ suppression of the inflammatory cytokine IL- $1 \beta$ expression as compared to the control. However, the individual SCFA exerted better suppression on inflammatory cytokine IL- $1 \beta$ expression as compared to the E. coli KUB-36 metabolites, except for the iso-valeric acid, which was not significantly different from E. coli KUB-36 metabolites. Surprisingly, acetic acid completely suppressed the inflammatory cytokine IL-1 $\beta$ expression (Fig. 7a), which have the same suppression profile as the inflammatory cytokine IL- 6 expression. The results showed that $E$. coli KUB-36 metabolites and individual SCFA that produced by E. coli KUB-36 metabolites have high suppression on the inflammatory cytokine IL-6 expression as compared to the control. Complete suppression of inflammatory cytokine IL- 6 expression was noted for E. coli KUB-36 metabolites, acetic acid, butyric acid, valeric acid and isovaleric acid (Fig. 7b). In comparison to the inflammatory cytokine IL-8 expression, $E$. coli KUB-36 metabolites and individual SCFA have lower suppression on the inflammatory cytokine expression than IL-1 $\beta$ and IL-6. Moreover, the individual SCFA still have better suppression on inflammatory cytokine IL-8 expression as compared to the E. coli KUB-36 metabolites, especially acetic acid which showed the highest suppression of inflammatory cytokine IL-8 expression (Fig. 7c).

As for the inflammatory cytokine TNF- $\alpha$ expression, the results obtained in this study showed that $E$. coli KUB-36 metabolites could suppress inflammatory cytokine TNF- $\alpha$ expression, but with lower suppression activity than the inflammatory cytokine IL- $1 \beta$ and IL-6 expression. Nevertheless, the individual SCFA, especially, acetic, butyric, iso-butyric and valeric acids elicited induced complete suppression on the inflammatory cytokine TNF- $\alpha$ expression (Fig. 7d).

Furthermore, the anti-inflammatory cytokine IL-10, which is the most important anti- inflammatory gene (normally expressed by macrophage cells) was also determined in this study. The results showed that the control did not express the IL-10 gene. Therefore, relative quantification or fold change could not be determined. Nonetheless, the treated sample showed indication of IL-10 expression (data not shown), hence, the results of IL-10 gene expression was normalized to the housekeeping genes (GAPDH and ACTP) and expressed as $\triangle \mathrm{Ct}$ value in present study. The $\Delta \mathrm{Ct}$ value of $E$. coli KUB-36 metabolites, iso-butyric acid, propionic acid and caproic acid were 5.10, 5.22, 2.26 and 3.56 respectively (data not shown), indicating that E. coli KUB-36 metabolites, isobutyric acid, propionic acid and caproic acid induced the expression of anti-inflammatory cytokine IL-10. However, acetic acid did not induce anti-inflammatory cytokine IL-10 expression.

\section{Discussion}

The human gut microbiota, especially the probiotic bacteria play an important role in gut homeostasis and have an impact on host metabolism and health. Among probiotic metabolites, SCFA is one of the postbiotic component that contributes greatly to maintain the GI tissue integrity and may positively affect the body's immune response [38]. Therefore, we selected the highest butyric acid producing bacteria, which was designated as E. coli KUB-36 for toxin gene detection, SCFA production profiles, anti-cancer and anti-inflammatory activities induced by its metabolites. The anti-cancer and antiinflammatory effects of individual SCFA that present in the E. coli KUB-36 metabolites were further verified in this study. In current study, E. coli KUB-36 were grown in vitro by using a synthetic medium of Wilkins Chalgren under anaerobic condition to produce SCFA and cell growth. The in vitro cultured condition was different from the in-vivo gut environment, whereby innate immune responses, anti-microbial peptides, oxygen barrier, secretory IgA, epithelial microvilli, epithelial tight junctions, epithelium metabolism, mucus barrier and quorum sensing were absent.

$E$. coli is a type of bacteria that normally lives in the intestine of human [39]. Most E. coli are harmless and help in the health maintenance of the digestive tract [40]. In this study, we observed that E. coli KUB-36 was rapidly grown in the Wilkina Chalgren medium and the greatest

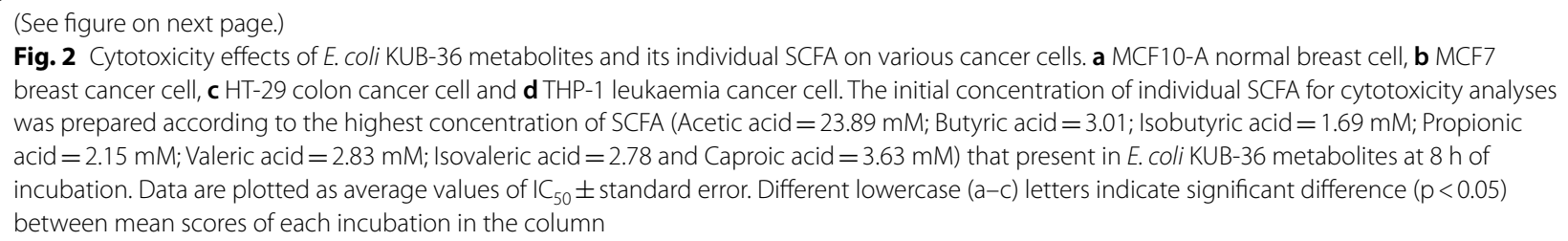



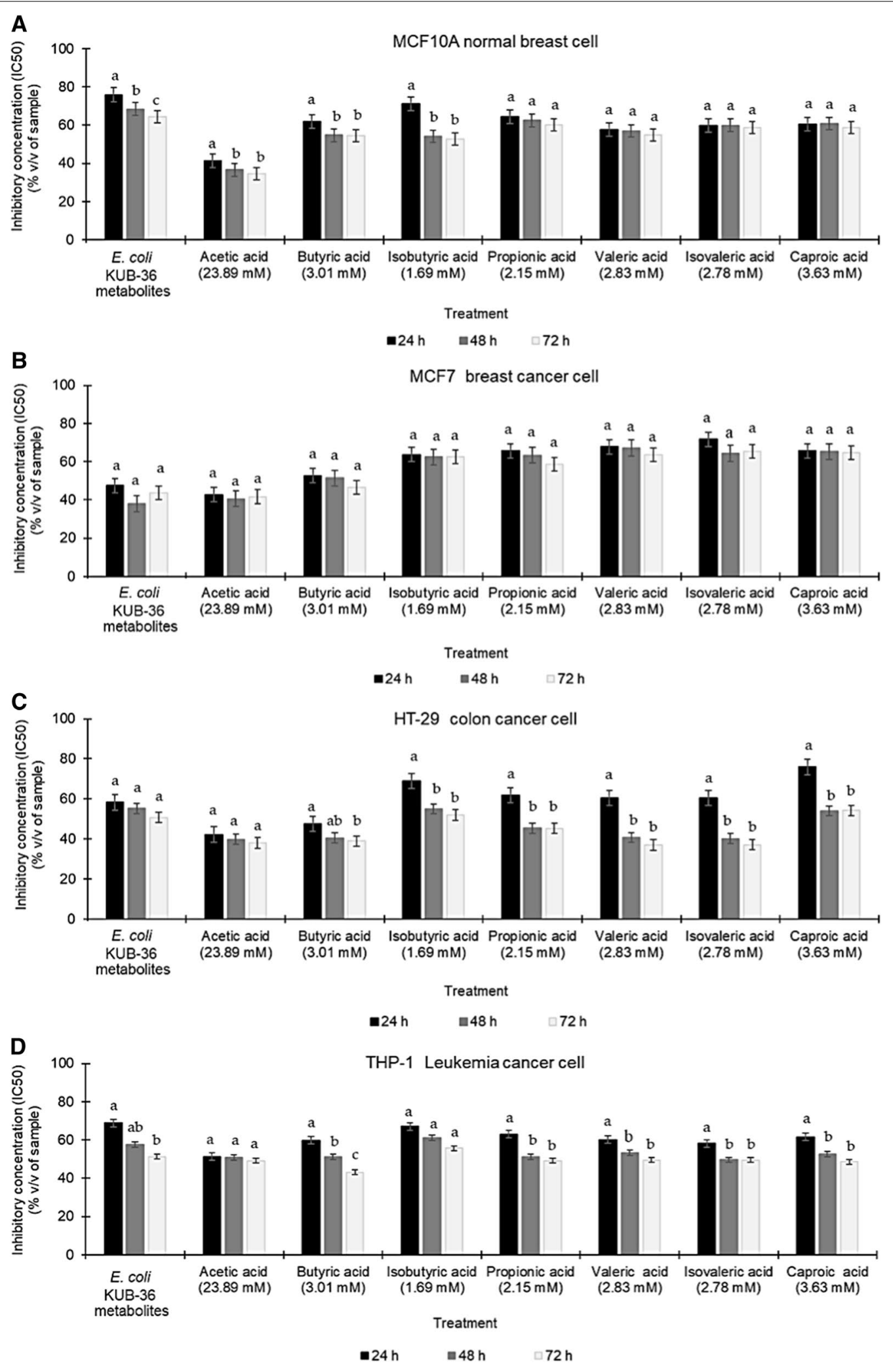


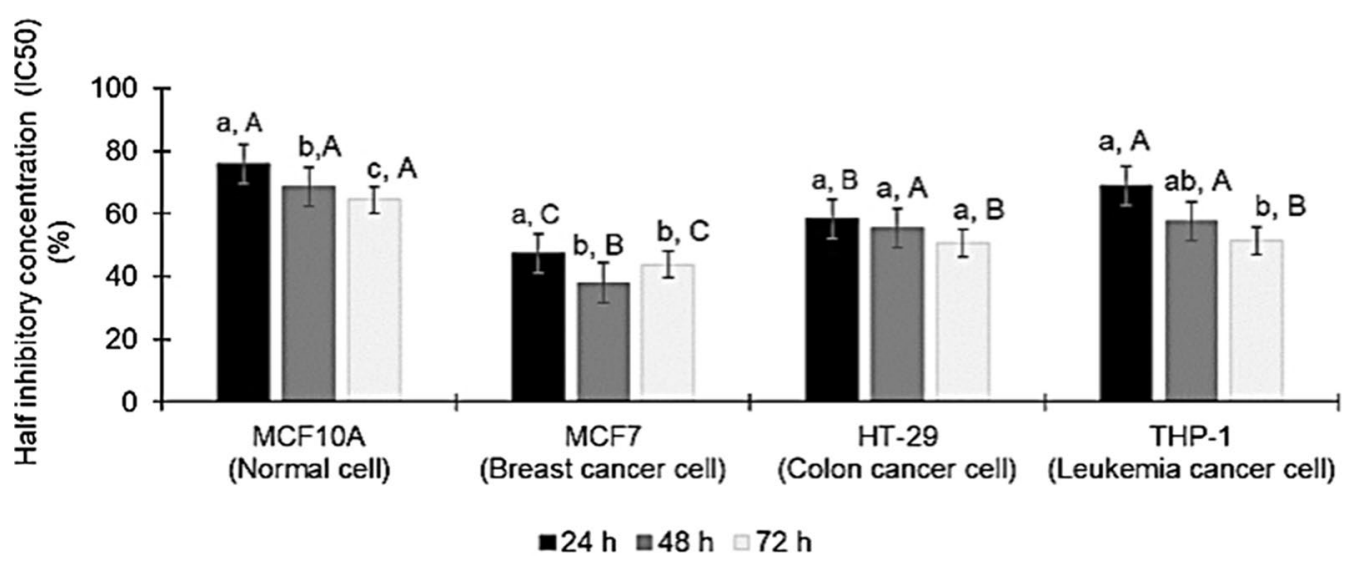

Fig. 3 Cytotoxicity effects of E. coli KUB-36 metabolites on various cancer cells. Data are plotted as average values of $I_{50} \pm$ standard error. Different lowercase $(a-b)$ letters indicate $(p<0.05)$ significant difference between mean scores of each incubation time in the column. Different uppercase $(A-C)$ letters indicate different $(p<0.05)$ between mean scores of each cancer cell type

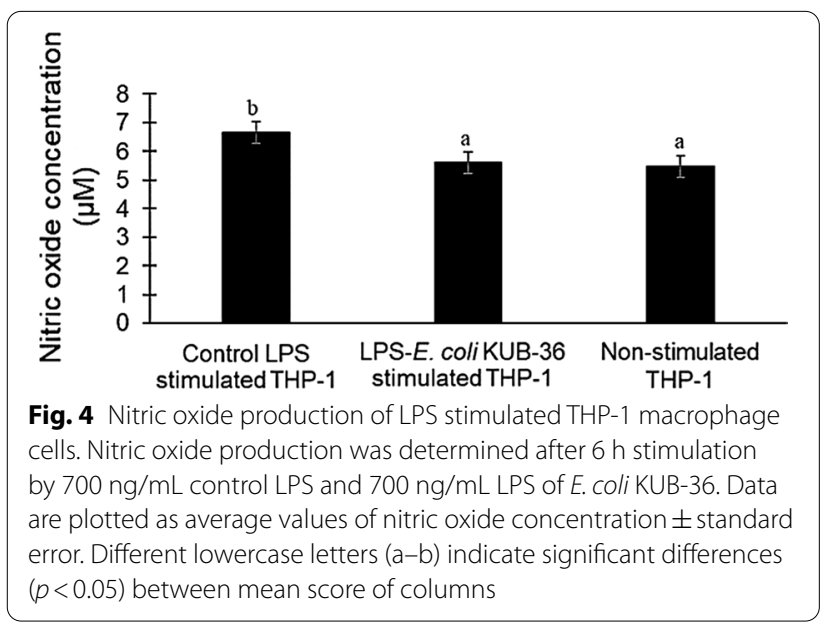

amounts of SCFA was produced after $8 \mathrm{~h}$ of incubation. In comparison, E. coli KUB-36 produced mainly acetic acid as a key product and minor amounts of butyric, isobutyric, propionic, valeric, isovaleric and caproic acids. The SCFA profile of E. coli KUB-36 was similar to probiotic E. coli Nissle 1917, whereby acetic acid and formic acid were produced mainly as compared to the minor amounts of propionic and butyric acids [41]. Acetic acid can be utilised as an energy source by the gut bacteria. Therefore, E. coli KUB-36 might be beneficial since it induced anti-inflammatory response while producing energy for other gut microbiome. The beneficial bacteria are mostly related to probiotic lactic acid bacteria and reports on SCFA are mostly based on whole metabolites produced by bacteria. Hence, in present study, we report the occurrence of beneficial SCFA-producing E. coli and the probiotic effects of individual SCFA that present in $E$. coli metabolites, which have not been reported elsewhere.
Although E. coli strains in the human intestine are harmless, the outer membrane of $E$. coli contains the potent immunostimulatory molecule lipopolysaccharide, which is known as endotoxin. Additionally, some E. coli strains harbour enterotoxin genes that are responsible for diarrhoea incidents [42, 43]. Therefore, the presence of both endotoxin and enterotoxin genes in $E$. coli KUB36 were verified in this study. Endotoxin that is known as LPS will be released upon destruction of the bacterial cell wall [44]. Endotoxins consist of: a) lipid A which is responsible for the toxicity of Gram-negative bacteria that can be recognized by the host innate immune system, b) a core polysaccharide that links the lipid A to the $\mathrm{O}$-antigen, the outermost part of the LPS molecule expressed on the bacteria cell wall, which is the major antigen targeted by the host antibody responses.

The lipid A biosynthetic pathway in E. coli comprises nine constitutive enzymes, which are LpxA, LpxB, LpxC, LpxD, LpxH, LpxK, LpxL, LpxM and WaaA [45]. Some E. coli may not harbour some of the genes encoding the lipid A biosynthetic enzymes. However, the genes encoding the first four enzymes (LpxA, LpxC, LpxD and LpxB) are often present in E. coli [46]. In this study, we could amplify the first four genes encoding lipid A: $\operatorname{lp} x A, \operatorname{lp} x B$, $l p x C$ and $l p x D$, which have been reported for E. coli. Lipid A of $E$. coli induces an inflammatory reaction in host cells. However, structurally different lipid A can result in weak inflammatory responses in the host and hence, it can be completely blocked by any pro-inflammatory reactions via binding to the corresponding host receptors [47]. The biosynthesis of the core polysaccharide is encoded by waa $F$ and waaC genes. Nevertheless, wzy and $w z z$ genes are the important genes that responsible for $\mathrm{O}$-antigen biosynthesis, whereby the $w z y$ gene is involved 


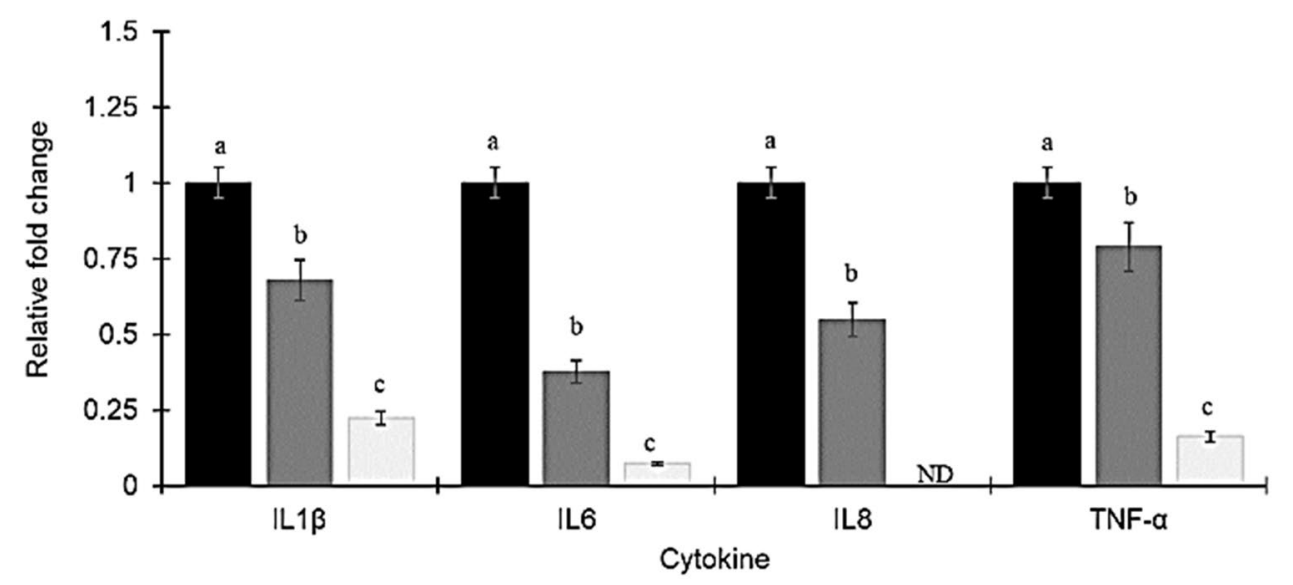

Control LPS stimulated THP-1

口 LPS-E.coli KUB-36 stimulated THP-1

$\square$ Non-stimulated THP-1

Fig. 5 Inflammatory cytokine gene expressions of LPS stimulated THP-1 macrophage cells. The inflammatory cytokine gene expressions were determined for non-stimulated THP-1 macrophage cells and THP-1 macrophage cells stimulated by $700 \mathrm{ng} / \mathrm{mL}$ control LPS and $700 \mathrm{ng} / \mathrm{mL}$ LPS KUB-36 for $r 6 \mathrm{~h}$. Inflammatory cytokine gene expression was expressed relative to THP-1 stimulated by control LPS, which was calculated by $2^{-\triangle \Delta C t}$ method. Data are plotted as average values of relative fold change \pm standard error. Different lowercase letters $(a-c)$ indicate $(p<0.05)$ significant differences $(p<0.05)$ between mean score from 6 replicates of each column

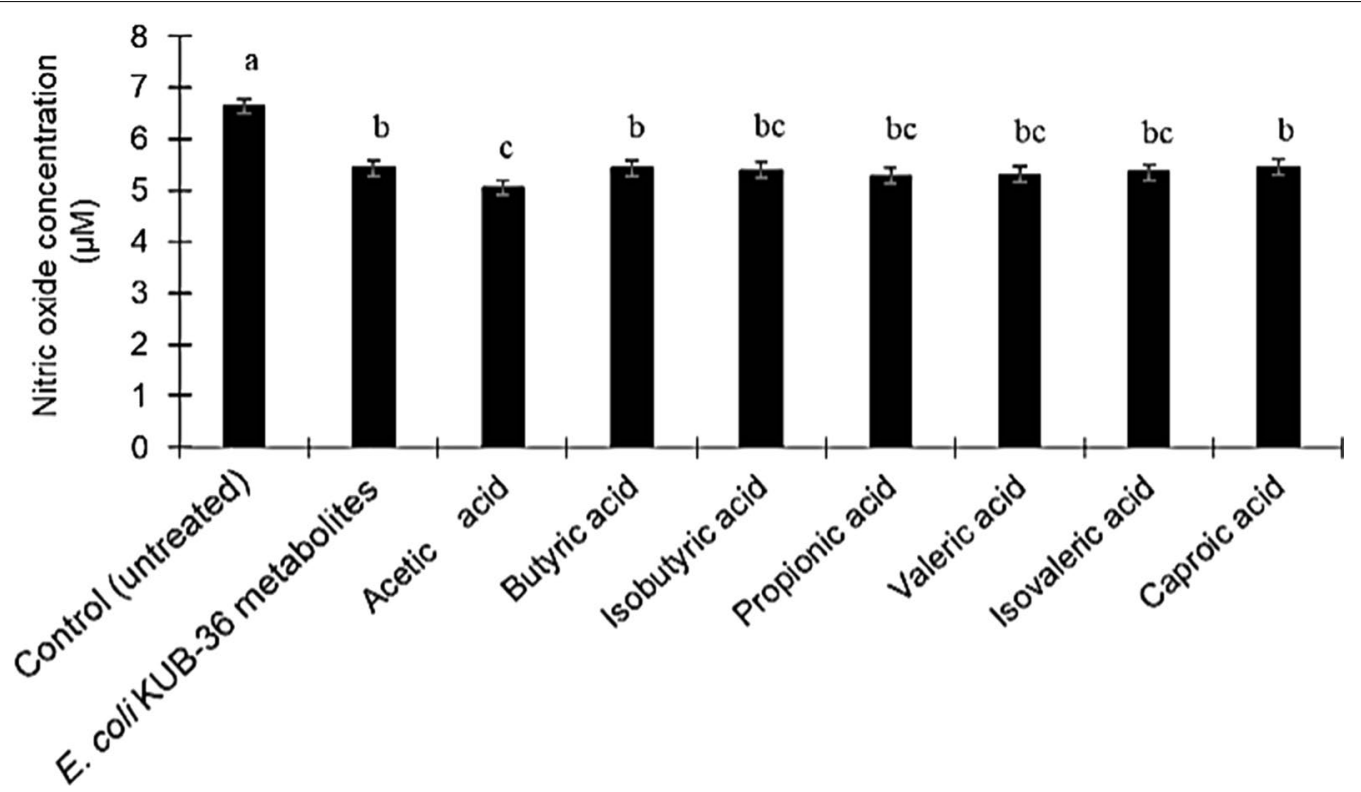

Fig. 6 Effects of E. coli KUB-36 metabolites and its individual SCFA on nitric oxide production of LPS-stimulated THP-1 macrophage cells. IC 50 values of E. coli KUB-36 metabolites and its individual SCFA were used in this experiment [E. coli metabolite; $I C_{50}=68.90 \%$, Acetic acid; $I C_{50}=51.30 \%$ $(12.26 \mathrm{mM})$; Butyric acid; $I C_{50}=59.88 \%(1.80 \mathrm{mM})$; Isobutyric acid; $I C_{50}=67.07 \%(1.13 \mathrm{mM})$; Propionic acid; $I C_{50}=63.63 \%$ (1.37 mM); Valeric acid; $I C_{50}=60.08 \%(1.70 \mathrm{mM})$; Isovaleric acid; $I C_{50}=58.27 \%(1.62 \mathrm{mM})$; Caproic acid; $\left.I C_{50}=61.56 \%(2.23 \mathrm{mM})\right]$. Data are plotted as average values of nitric oxide production \pm standard error. Different lowercase letters $(a-c)$ indicate significant differences $(p<0.05)$ between mean scores of columns

in the polymerization of $\mathrm{O}$-antigen subunits, while the $w z z$ gene functions as a molecular ruler to determine the O-antigen chain length that ligates to the terminal sugar residues of the core-lipid $\mathrm{A}$ in a reaction mediated by waaL. For comparison, only the waaF and wzy genes encoding the core polysaccharide and $\mathrm{O}$-antigen were amplified from E. coli KUB-36 in this study. The E. coli KUB-36 did not habour both waaL and wzz genes, which mediates the ligation of $\mathrm{O}$-antigen onto lipid $\mathrm{A}$-core and the regulation of the length of polysaccharide $\mathrm{O}$-antigen 


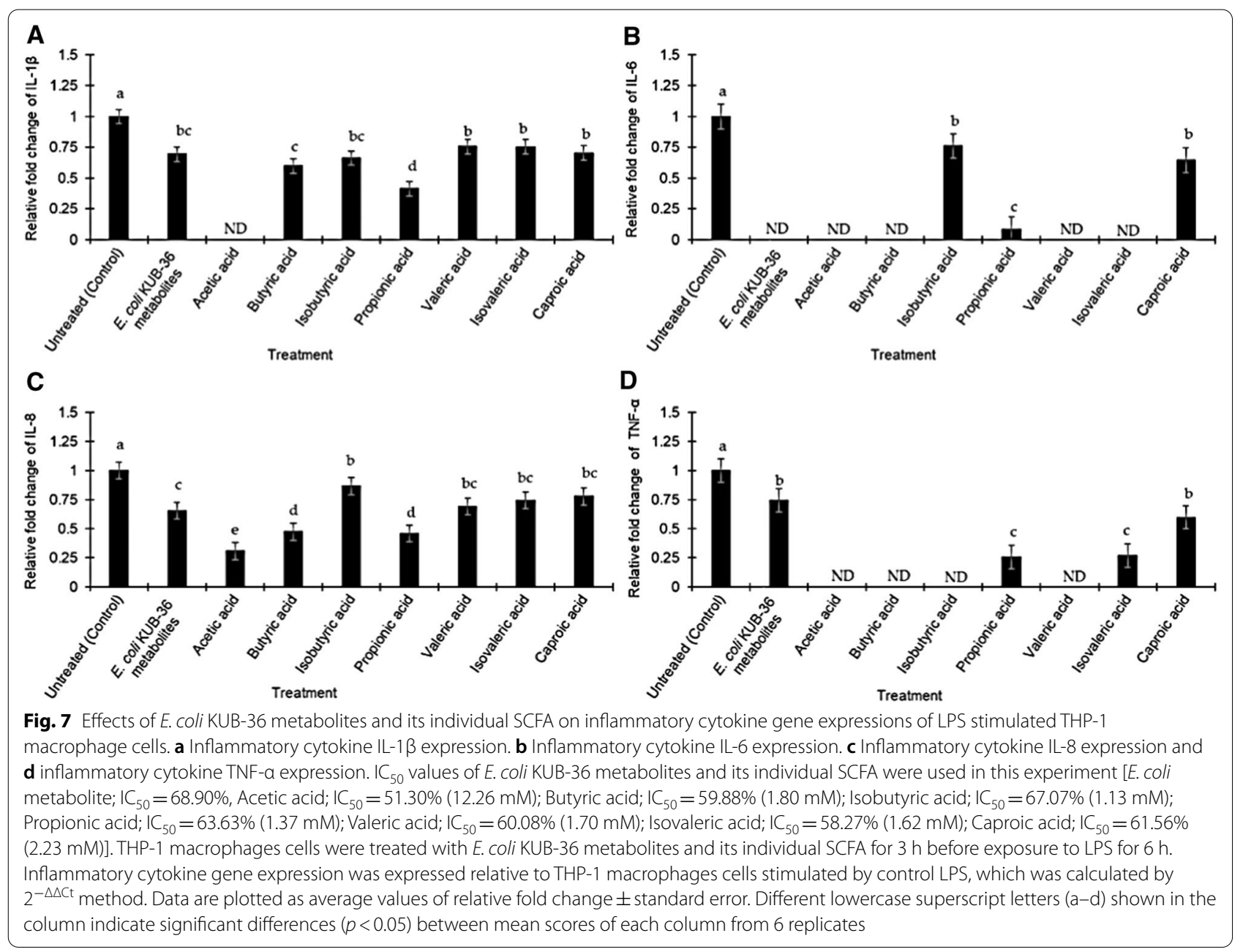

[48] respectively. Similar results were also reported for commensal E. coli K-12 [49]. Therefore, E. coli KUB-36 most likely possessed a defective LPS biosynthetic pathway without the presence of $\mathrm{O}$-antigen, attributing to the absent of the $w z z$ and waaL genes. Likewise, both heatlabile and heat-stable enterotoxin genes were also absent from E. coli KUB-36. Similarly, both probiotic E. coli Nissle 1917 and non-pathogenic E. coli K-12 did not harbour heat-labile and heat-stable enterotoxins gene $[6,47$, 50-53]. Therefore, the results of this study implied that E. coli KUB-36 is most likely a safe commensal bacterium.

Nowadays, bacteria are proposed to be used as an effective biotherapeutic agent in disease treatments, especially the gut microbiota. Cancer is reported to be a leading cause of death globally and is responsible for an estimated 9.6 million deaths in 2018 [9]. The increasing incidents of drug resistance in cancer treatment has urged a drastical and urgent attempt to search for a new drug for cancer treatments. Gut bacteria that could produce SCFA metabolites have been demonstrated to exert anti-cancer effects [11-16]. Moreover, SCFA are generally the fermentation product of gut microbiota. Importantly, SCFA have a role in gut and immune homeostasis, attributing to their potential anticancer properties, lipid metabolism, anti-inflammatory and other immune effects, including atopic diseases [4]. In this study, E. coli KUB-36 metabolites was demonstrated to have cytotoxicity effect on breast cancer cell, colon cancer cell and leukaemia cancer cell at 24, 48 and $72 \mathrm{~h}$ of incubation, whereby the highest cytotoxicity activity was detected for MCF7 breast cancer cell at 48 and $72 \mathrm{~h}$ of incubation. Furthermore, the individual SCFA also exhibited similar cytotoxicity effect as E. coli KUB-36 metabolites in a time and dose dependent manner. Previous studies have reported that $2-5 \mathrm{mM}$ of butyric acid could reduce the cell viability of colon cancer cell [54], breast cancer cell [55], and leukaemia cancer cell [56] respectively. Acetic and propionic acids at a concentration between $2-10 \mathrm{mM}$ and valeric acid at a concentration of $5 \mathrm{mM}$ could reduce the cell viability of colon cancer cell $[54,57]$. In addition, caproic acid at a 
concentration between $0.6-44 \mathrm{mM}$ exhibited anti-cancer activity on colon, skin and breast cancer cells [58]. Thus, the cytotoxicity activities of E. coli KUB-36 metabolite were most likely to be attributed to the extracellular SCFA produced by E. coli KUB-36. In the human host, the SCFA produced by the microbiota in the cecum and colon can be found in the hepatic, portal and peripheral blood circulation. However, most of the propionic and butyric acid from portal circulation are degraded in the liver to prevent high SCFA concentration in the blood circulation. Acetate is the only SCFA distributed throughout the circulation [3]. Therefore, the observed in vitro effects of cytotoxicity activity on breast cancer cells would differ considerably as compared to in vivo condition.

Proinflammatory cytokines are commonly induced by the LPS cell wall component of Gram-negative bacteria. Therefore, in this study we have made an attempt to investigate the structure of LPS of $E$. coli KUB-36, which could be involved in the immune response by inducing cytokines expression (IL-1 $\beta$, IL-6, IL- 8 and TNF- $\alpha$ ) and NO production. NO production of stimulated THP-1 cell with LPS of E. coli KUB-36 was not significantly different from the non-simulated THP-1 cell, which could be due to the absence of some core-polysaccharide and $\mathrm{O}$-antigen in the LPS of E. coli KUB-36. Likewise, the LPS of E. coli nissle 1917 was shown to have a very short $\mathrm{O}$-antigen polysaccharide side chain, whereby a stopcodon in the open reading frame (ORF) encoded the $\mathrm{O}$-antigen polymerase [52] was detected in E. coli nissle. However, the LPS of $E$. coli KUB-36 induced IL-1 $\beta$, IL-6, IL- 8 and TNF- $\alpha$ proinflammatory cytokines, despite having lower effect than the LPS of pathogenic bacteria since a defective lipid A was found on E. coli KUB-36 membrane. Thus, the immune response of the LPS was mainly induced by the lipid A moiety [23]. Similarly, the LPS from outer membrane of E. coli Nissle 1917 has been reported to elicit pro-inflammatory cytokine IL-1 $\beta$, IL-6, TNF- $\alpha$ and VEGF production $[4,59]$. However, E. coli Nissle 1917 metabolites have been shown to reduce proinflammatory cytokine, but nevertheless induced antiinflammatory cytokine [6], whereby the LPS of E. coli Nissle 1917 strain exhibited immunomodulating properties without showing immunotoxin effects [52].

Inflammation may be a trigger factor in various cancer incidents. In general, the longer persistence of inflammation will impose a higher risk to cancer incidents, whereby inflammatory mediators include cytokines, chemokines and free radicals that will lead to increased cell proliferation, mutagenesis oncogene activation and angiogenesis which promote cancer cell development. However, SCFA have been reported to exert anti-inflammatory effect, such as the reduction of IL- 8 production during airway inflammation via the activation of free fatty acid receptors 2 and 3 (FFA) of macrophages [60]. Furthermore, butyric and propionic acid have been shown to decrease LPS-induced TNF $\alpha$ and nitric oxide synthase (NOS) expression in monocytes [61]. Butyric acid upregulates IL-10 production and suppresses the production of pro-inflammatory molecules of IL-12, TNF $\alpha$, IL- $1 \beta$ and NO by inhibiting NF- $\mathrm{kB}$ activity $[12,16,62]$. Butyric acid also can decrease inducible NOS (iNOS), TNF $\alpha$, MCP-1 and IL-6 production by activation of FFA3 receptor [63] of macrophage cell. In addition, butyric and propionic acids have been demonstrated to suppress TNF $\alpha$ production and NF-kB activity, while promoting the production of anti-inflammatory cytokine IL-10 in LPS-activated mononuclear cells by inhibiting the histone deacetylases (HDACs) [14, 64, 65], whereas propionic acid was reported to inhibit $\mathrm{NO}$ production by NF- $\mathrm{kB}$ activation of macrophages [16] and acetic acid was reported to inhibit LPS-induced TNF $\alpha$ secretion from human mononuclear cells by activating FFA receptor pathways [16]. Therefore, we have made an investigation on the NO production and anti-inflammatory effect of $E$. coli KUB36 metabolite and individual SCFA.

In this study, E. coli KUB-36 metabolite and individual SCFA reduced the production of NO and proinflammatory cytokines IL- $1 \beta$, IL- 6 , IL- 8 and TNF- $\alpha$, inferring that E. coli KUB-36 metabolites and individual SCFA could affect inflammatory responses in LPS stimulated THP-1 macrophage cells. Moreover, the results obtained in this study implied that E. coli KUB-36 metabolites has similar effect to $E$. coli nissle 1917 metabolites, which could inhibit the production of cytokine IL-2, TNF- $\alpha$, and IFN$\gamma$, while promoting the production of anti-inflammatory cytokine IL-10 [6]. Nevertheless, the results of this study revealed that E. coli KUB-36 metabolite induced the gene expression of anti-inflammatory cytokine IL-10, despite individual acetic, butyric and propionic acid did not induce the anti-inflammatory cytokine IL-10 gene expression, suggesting that E. coli KUB-36 metabolites might contain other bioactive compounds that could induce the anti-inflammatory cytokine IL-10 expression.

\section{Conclusion}

In conclusion, this study demonstrated that the E. coli strains isolated from healthy human faeces produced different SCFA profile which could be considered as a safe commensal bacterium since they did not possess any toxin gene. The extracellular metabolites produced by the selected E. coli KUB- 36 strain exhibited lower cytotoxicity activity on normal MCF10A breast cell and THP-1 leukaemia cell but demonstrated higher cytotoxicity activity on both HT-29 colon cancer and MCF7 breast cancer cell. Furthermore, E. coli KUB-36 metabolites 
displayed anti-inflammatory effects on LPS-induced macrophage cells, since it suppressed well in the production of inflammatory cytokine IL-6, IL-8, IL-1 $\beta$ and TNF- $\alpha$. In comparison, E. coli KUB-36 metabolites that contained mainly acetic acid conferred highly positive effects on anti-inflammatory activity of macrophage cells by inducing the production of IL- $6, \mathrm{IL}-1 \beta$ and TNF- $\alpha$. The overall results of this study have provided strong evidence to support $E$. coli KUB-36 as a potential probiotic bacterium that could be used as a bioagent for inflammatory prevention and chemopreventive agent for cancer development and treatment.

\section{Methods}

\section{Isolation of gut bacteria and maintenance}

Ethics approval for this study was obtained within the framework of the study code KUREC-HS61/003 (2/ April/2018) given by the Kasetsart University Research Ethics Committee. The faecal sample was collected from three healthy volunteers aged between 25 and 60 years that was selected based on the following criteria: normal body mass index, did not have diseases, non-smoking, non-alcohol drinking, practice routine exercise and annual routine medical check-up. The faeces were aseptically transferred into a sterile tube containing Wilkins Chalgren anaerobic broth (Oxford, Basingstoke, UK) prior to flushing with $\mathrm{CO}_{2}$. The faeces samples were subjected to tenfold serial dilutions and mixed by vertexing for $3 \mathrm{~min}$. Total viable count was performed by using Wilkins Chalgren anaerobic agar that was incubated at $37^{\circ} \mathrm{C}$ under an anaerobic system (Bastron anaerobic chambers, Sheldon Co., Ltd., USA) fed with $5 \% \mathrm{CO}_{2}, 5 \%$ $\mathrm{H}_{2}$ and $90 \% \mathrm{~N}_{2}$ for $48 \mathrm{~h}$. Each colony was isolated by restreaking on Wilkins Chalgren anaerobic agar for 2-3 times. The isolates were then maintained by using $50 \%$ $(\mathrm{v} / \mathrm{v})$ glycerol and kept at $-20^{\circ} \mathrm{C}$ until further use.

\section{Bacterial culture and metabolites preparation}

Bacteria was revived by inoculation into Wilkins Chalgren anaerobic broth at $1 \%(\mathrm{v} / \mathrm{v})$ and incubated at $37^{\circ} \mathrm{C}$ for $24 \mathrm{~h}$ under anaerobic condition. The cultured supernatant of bacteria was collected and designated as metabolites after centrifugation at $2044 \times g, 4{ }^{\circ} \mathrm{C}$ for $15 \mathrm{~min}$.

\section{Determination of short chain fatty acid profile}

Gas chromatography (GC) is most used for SCFA analysis due to compatibility with the chemical properties of SCFA, such as volatility. Flame ionization detection (FID) is commonly used to detect the SCFA due to its inexpensive cost for operation, as well as its ability to detect a wide range of organic compounds. Therefore, GC was used for the determination of SCFA profile in this study. The SCFA profile of overnight cultured supernatant was analyzed by using GC (GC, Agilent 6890; Agilent Technologies, Palo Alto, CA, USA). The composition of acetic, propionic, iso-butyric, butyric, iso-valeric, valeric and caproic acids were determined for SCFA of cultured supernatant. To determine the SCFA concentration, $0.5 \mathrm{~mL}$ of 4-methyl-n-valeric acid (Sigma, Missouri, USA) was added to $0.5 \mathrm{~mL}$ of each cultured supernatant as an internal standard before being analysed by GC. The SCFA analysis was performed using a fused-silica capillary column $(30 \mathrm{~m} \times 0.25 \mu \mathrm{m} \times 0.25 \mu \mathrm{m})$ (Agilent 6890; Agilent Technologies, Palo Alto, California, USA) in a $\mathrm{GC}$ that equipped with FID detector. The flow rate of nitrogen as the carrier gas was $1.0 \mathrm{~mL} / \mathrm{min}$. The running conditions for SCFA analyses were maintained at $160{ }^{\circ} \mathrm{C}$ with FID detector at $250{ }^{\circ} \mathrm{C}$ and injector temperature at $230{ }^{\circ} \mathrm{C}$. The GC analyses for SCFA were conducted in triplicate for each metabolite.

\section{$16 \mathrm{~S}$ rRNA sequence analysis}

The selected bacteria were identified by performing a full length $16 \mathrm{~S}$ rRNA sequencing using universal primer sequence of 27F and 1492R (Ward Medic Co., Ltd., Bangkok, Thailand). The full length of $16 \mathrm{~S}$ rRNA sequences were aligned with the consensus sequences deposited at GenBank of NCBI and sequence alignment data were analysed by using BLAST software of the NCBI.

\section{DNA extraction}

Genomic DNA of selected bacteria was prepared using a Genomic DNA extraction mini kit according to the instruction of manufacturer (Yeastern Biotech Co., Ltd, Taipei, Taiwan). Briefly, bacteria cells were cultured at $37{ }^{\circ} \mathrm{C}$ for $24 \mathrm{~h}$ under anaerobic condition before centrifuging at $14,000 \times g$ at room temperature for $1 \mathrm{~min}$. The supernatant was then discarded and the bacterial cell pellet was resuspended with $50 \mu \mathrm{L}$ N1 Buffer, followed by adding $300 \mu \mathrm{L}$ of Lysis Buffer and incubated at $60{ }^{\circ} \mathrm{C}$ for $10 \mathrm{~min}$ until clear lysate was observed. To remove protein, $400 \mu \mathrm{L}$ Protein Removal Buffer was then added to the lysate mixture prior to centrifugation at $14,000 \times g$ for $1 \mathrm{~min}$, followed by washing the extracted DNA pellet twice with $400 \mu \mathrm{L}$ of Washing Buffer. Wash solutions were removed by centrifugation at $14,000 \times g$ for $30 \mathrm{~s}$ and the DNA pellet was then dried by centrifugation at $14,000 \times g$ for $3 \mathrm{~min}$. Purified DNA pellet was eluted with $90 \mu \mathrm{L}$ of preheated elution buffer $\left(75^{\circ} \mathrm{C}\right)$ for $3 \mathrm{~min}$, followed by centrifugation at $14,000 \times g$ for $2 \mathrm{~min}$. The purified DNA extract was kept at $-20^{\circ} \mathrm{C}$ until used.

\section{Toxin gene detection}

The presence of LPS endotoxin genes $(l p x A, l p x B, \operatorname{lp} x C$, lpxD, waaC, waaF, waaL, waaQ, wzy and wzz) and exotoxin genes (etlB, heat-labile; $S t b$, heat-stable) were 
verified for the selected $E$. coli strains using the primers listed in Table 1. The PCR condition for the amplification of the toxin genes were carried out as follows: DNA was denatured for 2 min at $95^{\circ} \mathrm{C}$ and amplified for 30 cycles $\left(30 \mathrm{~s}\right.$ at $95{ }^{\circ} \mathrm{C}, 30 \mathrm{~s}$ at $48-63{ }^{\circ} \mathrm{C}, 1 \mathrm{~min}$ at $72{ }^{\circ} \mathrm{C}$ for denaturation, annealing and extension phases, respectively), followed by additional period of $10 \mathrm{~min}$ extension at $72{ }^{\circ} \mathrm{C}$. PCR products were separated by electrophoresis using $1 \%(w / v)$ agarose gel and stained with $0.5 \%(v / v)$ nucleic acids stain. The amplified bands were visualized and recorded under UV illumination.

\section{Cell culture and maintenance}

Colorectal cancer cells HT-29 were provided by the Tissue Culture Laboratory of UPM, whereas human breast cancer cells MCF-7, human normal breast cell MCF-10A (reference of normal glandular epithelium) and THP-1 leukaemia cancer cell were purchased from American Type Culture Collection (ATCC). Human normal breast cell MCF-10A was cultured in Dulbecco's Modified Eagle Medium (DMEM) (Invitrogen, Carlsbad, CA, USA) supplemented with $0.01 \mathrm{mg} / \mathrm{ml}$ insulin and $10 \%$ fetal bovine serum (FBS), Human breast cancer cells MCF-7, cultured in DMEM supplemented with $20 \mathrm{ng} / \mathrm{ml}$ EFG, $0.5 \mu \mathrm{g} /$ $\mathrm{ml}$ hydrocortisol, $5 \%$ horse serum, and $10 \mu \mathrm{g} / \mathrm{ml}$ insulin. Colorectal cancer cells HT-29 was cultured in RPMI (Gibco, USA) supplemented with 10\% (v/v) FBS, $100 \mathrm{UI} /$ $\mathrm{ml}$ of penicillin-streptomycin. All cells were maintained at $37^{\circ} \mathrm{C}$ under $5 \% \mathrm{CO}_{2}$ atmosphere.

\section{Cytotoxic effect of selected E. coli KUB-36 metabolites and individual SCFA}

Normal and cancer cells were seeded onto 96-well microplates at $1 \times 10^{5}$ cells $/ \mathrm{mL}$ and incubated at $37{ }^{\circ} \mathrm{C}$ in a $5 \%$ $\mathrm{CO}_{2}$ incubator for cytotoxicity assay. The initial concentration of individual SCFA for cytotoxicity analyses was prepared according to the highest concentration of SCFA (Acetic acid $=23.89 \mathrm{mM}$; Butyric acid $=3.01$; Isobutyric acid $=1.69 \mathrm{mM}$; Propionic acid $=2.15 \mathrm{mM}$; Valeric acid $=2.83 \mathrm{mM}$; Isovaleric acid $=2.78$ and Caproic acid $=3.63 \mathrm{mM}$ ) that present in E. coli KUB-36 metabolites at $8 \mathrm{~h}$ of incubation (Table 2). For the determination of $\mathrm{IC}_{50}$ value, two-fold dilution was conducted for E. coli KUB-36 metabolite and individual SCFA by using growth medium to achieve the final concentrations of $1.56-100 \%(\mathrm{v} / \mathrm{v})$. At the respective incubation time of $24 \mathrm{~h}, 48 \mathrm{~h}$ and $72 \mathrm{~h}$, a volume of $20 \mu \mathrm{L}$ of 3-(4,5-dimethylthiazol-2-yl)-2,5-diphenyl tetrazolium bromide (MTT) solution (Sigma, MO, USA) ( $5 \mathrm{mg} / \mathrm{mL}$ in PBS) was added to each well and incubated for $4 \mathrm{~h}$ in dark condition after removing the treatment mixture from each well. Then, $100 \mu \mathrm{L}$ of dimethylsulfoxide (DMSO) (Fisher Scientific,
Loughborough, UK) were added to each well and mix thoroughly by pipetting 10-20 times to dissolve the blue formazan crystals. The absorbance of the formazan dye was quantified by a Quant ELISA reader (Biotek EL340, Vermont, USA) at $570 \mathrm{~nm}$ with a reference wavelength of $630 \mathrm{~nm}$. The experiment was repeated three times with triplicate samples. The following equation was used to calculate the percentage of cell viability:

$$
\frac{\left(A_{\text {sample }}-A_{\text {blank }}\right)}{\left(A_{\text {control }}-A_{(\text {blank })}\right)} \times 100
$$

$\mathrm{A}_{\text {sample }}$ represents the absorbance of cells treated with metabolites or individual SCFA; $A_{\text {blank }}$ represents absorbance of the growth media and $\mathrm{A}_{\text {control }}$ represents absorbance of untreated cells. The concentration for $50 \%$ of growth $\left(\mathrm{IC}_{50}\right)$ was determined by plotting the percentage of cell viability versus the concentration of metabolites and individual SCFA, respectively.

\section{Extraction of E. coli KUB-36 lipopolysaccharide}

LPS of E. coli KUB-36 was extracted by using LPS extraction kit (100 Rxn, iNtRON Biotechnology, Incheon, Korea) according to the instruction of manufacturer. Briefly, 2-5 ml of E. coli KUB-36 cells were collected by centrifugation at $14,000 \times g$ for $10 \mathrm{~min}$ at room temperature, followed by adding $1 \mathrm{ml}$ of lysis buffer to lysis the bacterial cell by vertexing vigorously. After the addition of $200 \mu \mathrm{l}$ of chloroform, the lysis mixture was centrifuged at $14,000 \times g$ for $10 \mathrm{~min}$ at $4{ }^{\circ} \mathrm{C}$ prior to the collection of $400 \mu \mathrm{l}$ of upper aqueous layer. A volume of $800 \mu \mathrm{l}$ of purification buffer was then added to the $400 \mu \mathrm{l}$ of upper aqueous layer before incubation at $-20{ }^{\circ} \mathrm{C}$ for $10 \mathrm{~min}$. The extracted LPS was collected by centrifugation at $14,00 \times g$ for $15 \mathrm{~min}$ at $4{ }^{\circ} \mathrm{C}$, followed by washing twice with $1 \mathrm{ml}$ of $70 \%(\mathrm{v} / \mathrm{v})$ ethanol. The washed LPS pellet was collected by centrifugation at $14,000 \times g$ for $3 \mathrm{~min}$ at $4{ }^{\circ} \mathrm{C}$ and the upper layer was discarded. The remaining LPS pellet was the allowed to dry at room temperature.

\section{Nitric oxide production}

The NO concentration was determined by measuring the amount of nitrite in the cell culture supernatant using a Nitric Oxide Detection Kit (iNtRON Biotechnology, Incheon, Korea). A $100 \mu \mathrm{L}$ aliquot of the cell culture supernatant was mixed with $100 \mu \mathrm{L}$ of Griess reagent and the mixture was incubated for $10 \mathrm{~min}$ at room temperature. The absorbance was measured at $540 \mathrm{~nm}$ using a Quant ELISA reader (Biotek EL340, Vermont, USA).

\section{THP-1 cell differentiation}

The human monocytic leukaemia cell line THP-1 (American Type Culture Collection, Rockville, MD) was grown 
in RPMI 1640 culture medium (Sigma, Neustadt, Germany) supplemented with $10 \%(v / v)$ FBS (Invitrogen, $\mathrm{UK})$ and $1 \%(v / v)$ penicillin/streptomycin $(\mathrm{P} / \mathrm{S})$ (Invitrogen) at $37{ }^{\circ} \mathrm{C}$ in $5 \% \mathrm{CO}_{2}$ humidified incubator. Cells were sub-cultured at $72 \mathrm{~h}$ intervals. The macrophage-like cells were obtained by treating $1 \mathrm{~mL}$ of $10^{6} \mathrm{THP}-1$ monocytes/ well with $100 \mathrm{ng} / \mathrm{mL}$ phorbol 12-myristate 13-acetate (PMA; Sigma, Neustadt, Germany) for $48 \mathrm{~h}$ in a 12-wells cell culture plate (Greiner, Frankenhauser, Germany). Differentiated and plastic-adherent macrophage-like cells were then washed twice with RPMI culture medium and rested for another $24 \mathrm{~h}$ with culture medium to obtain the resting state of macrophages.

\section{Inflammation gene expression of THP-1 Macrophage}

THP-1 macrophages were pre-incubated with culture medium mixed with $\mathrm{IC}_{50}$ concentrations of $E$. coli $\mathrm{KUB}$ 36 metabolite and individual SCFA (E. coli KUB-36 metabolite; $\mathrm{IC}_{50}=68.90 \%$, Acetic acid; $\mathrm{IC}_{50}=51.30 \%$ $(12.26 \mathrm{mM})$; Butyric acid; $\mathrm{IC}_{50}=59.88 \%(1.80 \mathrm{mM})$; Isobutyric acid; $\mathrm{IC}_{50}=67.07 \%(1.13 \mathrm{mM})$; Propionic acid; $\mathrm{IC}_{50}=63.63 \%(1.37 \mathrm{mM})$; Valeric acid; $\mathrm{IC}_{50}=60.08 \%$ $(1.70 \mathrm{mM})$; Isovaleric acid; $\mathrm{IC}_{50}=58.27 \%(1.62 \mathrm{mM})$; Caproic acid; $\mathrm{IC}_{50}=61.56 \%(2.23 \mathrm{mM})$ in a 12-wells cell culture plate for $3 \mathrm{~h}$ prior to the additional incubation of $6 \mathrm{~h}$ with $700 \mathrm{ng} / \mathrm{mL}$ LPS. THP- 1 macrophages treated with culture medium containing PBS was employed as the control for this experiment. The expression of inflammatory and anti-inflammatory genes (Table 3 ) was determined by using $\mathrm{qPCR}$. The experiment was repeated twice with triplicate samples.

\section{RNA extraction and quantification}

Total RNA was extracted with MN NucleoSpin ${ }^{\circledR}$ RNA Plus KIT (Macherey-Nagel) according to the instructions of manufacturer. Briefly, the cell was added with $350 \mu \mathrm{l}$ of lysis buffer before transferring to a column fixed in the collection tube and centrifuged at $11,000 \times g$ for $30 \mathrm{~s}$. Then, $100 \mu \mathrm{L}$ of binding solution was added to the column and centrifuged at $11,000 \times g$ for $15 \mathrm{~s}$. The cell pellet was washed thrice with $400 \mu \mathrm{l}$ of washing buffer. Wash solutions were removed by centrifugation at $11,000 \times g$ for $15 \mathrm{~s}$ and dried by centrifugation at $11,000 \times g$ for $2 \mathrm{~min}$. Purified RNA was eluted by adding $30 \mu \mathrm{L}$ RNasefree $\mathrm{H}_{2} \mathrm{O}$ and collected by centrifugation at $11,000 \times g$ for $1 \mathrm{~min}$. The quality of the extracted RNA was determined by using BioSpectrometer kinetic (Eppendorf, Hamburg, Germany). The purity of RNA was determined from the adsorption ratio of $260 / 280$. The extracted RNA that achieved more than 2.00 for the adsorption ratio of $260 / 280$ was used for subsequent procedure.

\section{Reverse transcription (RT) and pre-amplification of cDNA}

cDNA was prepared from the extracted RNA by reverse transcription using $5 \mu \mathrm{L}$ Reverse Transcription Master mix (Fluidigm, California, USA). The resulted cDNA was then pre-amplified by using PreAmp Master mix (Fluidigm) with 7 custom-designed primers (designed by using Delta Gene assays according to the manufacturer's instructions). The pre-amplification reactions were performed with BioRad MyCycler Thermal Cycler (Bio-Rad Laboratories, Inc.) using the following amplification conditions: $95^{\circ} \mathrm{C}$ for $2 \mathrm{~min}$, followed by 14 cycles of $95^{\circ} \mathrm{C}$ for $15 \mathrm{~s}$ and $60^{\circ} \mathrm{C}$ for $4 \mathrm{~min}$.

\section{Inflammation gene expression analysis}

Gene expression analysis was performed with BioMark software (Fluidigm, California, USA). Quantitative PCR reaction were carried out in a Flex $\operatorname{Six}^{\mathrm{TM}}$ Genotyping IFC chip (Fluidigm, CA, USA). RT-qPCR was performed on

Table 3 Primer sequences of RT-qPCR used for the analyses of inflammatory and anti-inflammatory gene expressions of LPS-stimulated THP-1 macrophage cells

\begin{tabular}{|c|c|c|}
\hline & Specific gene & Primer \\
\hline \multirow[t]{5}{*}{ Cytokines gene } & $\mathbb{L L}-1 \beta$ & $\begin{array}{l}\text { F-GTGGCAATGAGGATGACTTGTTC } \\
\text { R-TAGTGGTGGTCGGAGATTCGTA }\end{array}$ \\
\hline & $\mathbb{I L}-6$ & $\begin{array}{l}\text { F-AGCCACTCACCTCTTCAGAAC } \\
\text { R-GCCTCTTTGCTGCTTTCACAC }\end{array}$ \\
\hline & $\mathbb{I L}-8$ & $\begin{array}{l}\text { F-CTGATTTCTGCAGCTCTGTG } \\
\text { R-GGGTGGAAAGGTTTGGAGTATG }\end{array}$ \\
\hline & $1 L-10$ & $\begin{array}{l}\text { F-GTGATGCCCCAAGCTGAGA } \\
\text { R-CACGGCCTTGCTCTTGTTTT }\end{array}$ \\
\hline & TNF-a & $\begin{array}{l}\text { F-CTGCTGCACT TTGGAGTGAT } \\
\text { R-AGATGATCTG ACTGCCTGGG }\end{array}$ \\
\hline \multirow[t]{2}{*}{ Housekeeping gene } & ACTB ( $\beta$-actin) & $\begin{array}{l}\text { F-ATTGCCGACAGGATGCAGAA } \\
\text { R-GCTGATCCACATCTGCTGGAA }\end{array}$ \\
\hline & $\begin{array}{l}\text { GAPDH } \\
\text { (Glyceraldehyde-3-phosphatedehydrogenase) }\end{array}$ & $\begin{array}{l}\text { F-CAACAGCGACACCCACTCCT } \\
\text { R-CACCCTGTTGCTGTAGCCAAA }\end{array}$ \\
\hline
\end{tabular}


a Biomark HD system (Fluidigm, California, USA) using the following thermocycling conditions: $70{ }^{\circ} \mathrm{C}$ for $2400 \mathrm{~s}$, $60{ }^{\circ} \mathrm{C}$ for $30 \mathrm{~s}, 95{ }^{\circ} \mathrm{C}$ for $60 \mathrm{~s}$, followed by 30 cycles of $96{ }^{\circ} \mathrm{C}$ for $5 \mathrm{~s}$ and $60{ }^{\circ} \mathrm{C}$ for $20 \mathrm{~s}$. The relative quantification method of $2^{-\Delta \Delta \mathrm{ct}}$ of Fluidigm real-time PCR software Version 4.3.1 (Fluidigm, California, USA) was employed for the gene expression data analyses.

\section{Statistical analysis}

Analysis of variance (ANOVA) was used for the data analyses in this study and the comparison of means was determined by using Duncan's multiple range tests of SPSS version 22 (SPSS, Inc) at $p \leq 0.05$.

\section{Abbreviations \\ COX-2: Cyclooxygenase-2; E. coli: Escherichia coli; FFA3: Free fatty acid receptor 3; HDACs: Histone deacetylases; IC50: Inhibition concentration of 50\% growth; IL: Interleukins; LPS: Lipopolysaccharide; NO: Nitric oxide; ORF: Open reading frame; SCFA: Short chain fatty acid(s); TNF-a: Tumor necrosis factor a.}

\section{Acknowledgments}

The authors would like to thank the Southeast Asian Regional Center for Graduate Study and Research in Agriculture (SEARCA), Laguna, Philippines and the Ministry of Higher Education of Malaysia for funding the research grant under Fundamental Research Grant Scheme (FRGS). The authors also would like to express sincere gratitude to the support given by the Department of Biotechnology, Kasetsart university, Thailand; Department of Bioprocess Technology, Faculty of Biotechnology and Biomolecular Sciences, Universiti Putra Malaysia, Malaysia and Institute of Bioscience, Universiti Putra Malaysia, Malaysia.

\section{Authors' contributions}

AN, HLF, AAS, NEAM, UW, SN. AN carried out the current study and drafted the manuscript. HLF participated in the funding acquisition, conceptualization, resources, design, conceived, coordination and supervision of this study; and helped in data curation, drafting and revising of manuscript. AAS participated in the supervision, validation; and helped to draft and revised the manuscript. NEAM participated in methodology and supervision. SN involved in conceptualization, funding acquisition, project administration, resources, supervision, validation, writing review and draft editing. UW involved in conceptualization, data curation, funding acquisition, methodology, project administration, resources, supervision, validation, writing original draft and editing. All authors read and approved the final manuscript.

\section{Funding}

This study was supported by the Southeast Asian Regional Center for Graduate Study and Research in Agriculture (SEARCA), Laguna, Philippines, The Fundamental Research Fund of the Malaysia Ministry of Higher Education (Grant No. FRGS/1/2016/STG05/UPM/02/13) and Kasetsart University Research and Development Institute (KURDI) (Grant No. 184.61).

\section{Availability of data and materials}

The datasets used and/or analysed during this study are available from the corresponding authors on reasonable request.

\section{Ethics approval and consent to participate}

Ethics was approved by Kasetsart University Research Ethics Committee (study code KUREC-HS61/003).

\section{Consent for publication}

All authors consented on the publication of this work.

\section{Competing interests}

The authors declare that they have no competing interests.

\section{Author details}

${ }^{1}$ Department of Bioprocess Technology, Faculty of Biotechnology and Biomolecular Sciences, Universiti Putra Malaysia, 43400 UPM Serdang, Selangor, Malaysia. ${ }^{2}$ Department of Biotechnology, Faculty of Agro-Industry, Kasetsart University, Chatuchak 10900, Bangkok, Thailand. ${ }^{3}$ Institute of Bioscience, Universiti Putra Malaysia, 43400 UPM Serdang, Selangor, Malaysia. ${ }^{4}$ Department of Microbiology, Faculty of Biotechnology and Biomolecular Sciences, Universiti Putra Malaysia, 43400 UPM Serdang, Selangor, Malaysia. ${ }^{5}$ Agro-Biotechnology Institute, National Institutes of Biotechnology Malaysia, 43000 UPM Serdang, Selangor, Malaysia. ${ }^{6}$ Fermentation Technology Research Center, Faculty of Agro-Industry, Kasetsart University, Chatuchak 10900, Bangkok, Thailand.

Received: 18 May 2020 Accepted: 19 November 2020

Published online: 05 February 2021

\section{References}

1. Rivière A, Selak M, Lantin D, Leroy F, De Vuyst L. Bifidobacteria and butyrate-producing colon bacteria: Importance and strategies for their stimulation in the human gut. Front Microbiol. 2016;7:25.

2. Lozupone CA, Stombaugh JI, Gordon JI, Jansson JK, Knight R. Diversity, stability and resilience of the human gut microbiota. Nature. 2012;489:220-30

3. Den Besten G, Van Eunen K, Groen AK, Venema K, Reijngoud DJ, Bakker $\mathrm{BM}$. The role of short-chain fatty acids in the interplay between diet, gut microbiota, and host energy metabolism. J Lipid Res. 2013;54:2325-40.

4. Macfarlane GT, Macfarlane S. Bacteria, colonic fermentation, and gastrointestinal health. J AOAC Int. 2012;95:50-60.

5. Havenaar R. Intestinal health functions of colonic microbial metabolites: a review. Benef Microbes. 2011;2:103-14.

6. Sonnenborn U, Schulze J. The non-pathogenic Escherichia coli strain Nissle 1917-features of a versatile probiotic. Microb Ecol Health Dis. 2009;21:122-58.

7. Ríos-Covián D, Ruas-Madiedo P, Margolles A, Gueimonde M, De los ReyesGavilán CG, Salazar N. Intestinal short chain fatty acids and their link with diet and human health. Front Microbiol. 2016;7:1-9.

8. Han KJ, Lee NK, Park H, Paik HD. Anticancer and anti-inflammatory activity of probiotic lactococcus lactis nk34. J Microbiol Biotechnol. 2015;25:1697-701.

9. WHO. Cancer. 2018. https://www.who.int/news-room/fact-sheets/detail/ cancer. Accessed September 12, 2019.

10. Hassan Z. Anti-cancer and biotherapeutic potentials of probiotic bacteria. J Cancer Sci Ther. 2019;11:9-13.

11. Mu MM, Chakravortty D, Sugiyama T, Koide N, Takahashi K, Mori I, et al. The inhibitory action of quercetin on lipopolysaccharide-induced nitric oxide production in RAW 264.7 macrophage cells. J Endotoxin Res. 2001;7:431-8.

12. Säemann MD, Böhmig GA, Österreicher $\mathrm{CH}$, Burtscher $\mathrm{H}$, Parolini $\mathrm{O}$, Diakos $C$, et al. Anti-inflammatory effects of sodium butyrate on human monocytes: potent inhibition of IL-12 and up-regulation of IL-10 production. FASEB J. 2000;14:2380-2.

13. Fukae J, Amasaki Y, Yamashita Y, Bohgaki T, Yasuda S, Jodo S, et al. Butyrate suppresses tumor necrosis factor a production by regulating specific messenger RNA degradation mediated through a cis-acting AU-rich element. Arthritis Rheum. 2005;52:2697-707.

14. Chang PV, Hao L, Offermanns S, Medzhitov R. The microbial metabolite butyrate regulates intestinal macrophage function via histone deacetylase inhibition. Proc Natl Acad Sci USA. 2014;111:2247-52.

15. Park JS, Woo MS, Kim SY, Kim WK, Kim HS. Repression of interferon$\gamma$-induced inducible nitric oxide synthase (iNOS) gene expression in microglia by sodium butyrate is mediated through specific inhibition of ERK signaling pathways. J Neuroimmunol. 2005;168:56-64.

16. Usami M, Kishimoto K, Ohata A, Miyoshi M, Aoyama M, Fueda Y, et al. Butyrate and trichostatin $\mathrm{A}$ attenuate nuclear factor $\mathrm{KB}$ activation and tumor necrosis factor a secretion and increase prostaglandin E2 secretion in human peripheral blood mononuclear cells. Nutr Res. 2008;28:321-8. 
17. Sokol H, Pigneur B, Watterlot L, Lakhdari O, Bermúdez-Humarán LG, Gratadoux JJ, et al. Faecalibacterium prausnitzii is an anti-inflammatory commensal bacterium identified by gut microbiota analysis of Crohn disease patients. Proc Natl Acad Sci U S A. 2008;105:16731-6.

18. Miquel S, Martín R, Rossi O, Bermúdez-Humarán LG, Chatel JM, Sokol H, et al. Faecalibacterium prausnitzii and human intestinal health. Curr Opin Microbiol. 2013;16:255-61.

19. Okada Y, Tsuzuki Y, Hokari R, Komoto S, Kurihara C, Kawaguchi A, et al. Anti-inflammatory effects of the genus Bifidobacterium on macrophages by modification of phospho-IKB and SOCS gene expression. Int J Exp Pathol. 2009;90:131-40.

20. Khokhlova EV, Smeianov VV, Efimov BA, Kafarskaia LI, Pavlova SI, Shkoporov AN. Anti-inflammatory properties of intestinal Bifidobacterium strains isolated from healthy infants. Microbiol Immunol. 2012;56:27-39.

21. Rocha-Ramírez LM, Pérez-Solano RA, Castañón-Alonso SL, Moreno Guerrero SS, Ramírez Pacheco A, García Garibay M, et al. Probiotic Lactobacillus strains stimulate the inflammatory response and activate human macrophages. J Immunol Res. 2017:2017:22.

22. Oh NS, Joung JY, Lee JY, Kim Y. Probiotic and anti-inflammatory potential of Lactobacillus rhamnosus 4B15 and Lactobacillus gasseri 4M13 isolated from infant feces. PLoS ONE. 2018;13:1-15.

23. Güttsches AK, Löseke S, Zähringer U, Sonnenborn U, Enders C, Gatermann $\mathrm{S}$, et al. Anti-inflammatory modulation of immune response by probiotic Escherichia coli Nissle 1917 in human blood mononuclear cells. Innate Immun. 2012;18:204-16.

24. Tsilingiri K, Barbosa T, Penna G, Caprioli F, Sonzogni A, Viale G, et al. Probiotic and postbiotic activity in health and disease: Comparison on a novel polarised ex-vivo organ culture model. Gut. 2012;61:1007-15.

25. Foo HL, Loh T, Law F, Lim Y, Kufli CN, Rusul G. Effects of feeding Lactobacillus plantarum I-UL4 isolated from Malaysian Tempeh on growth performance, faecal flora and lactic acid bacteria and plasma cholesterol concentrations in postweaning rats. Food Sci Biotechnol. 2003;12:403-8.

26. Loh TC, Chong SW, Foo HL, Law FL. Effects on growth performance, faecal microflora and plasma cholesterol after supplementation of spray-dried metabolite to postweaning rats. Czech J Anim Sci. 2009;54:10-6.

27. Foo HL, Loh TC, Lai PW, Lim YZ, Kufli CN, Rusul G. Effects of adding Lactobacillus plantarum I-UL4 metabolites in drinking water of rats. Pakistan J Nutr. 2003;2:283-8.

28. Thanh N, Loh T, Foo HL, Hair-Bejo M, Azhar BK. Effects of feeding metabolite combinations produced by Lactobacillus plantarum on growth performance, faecal microbial population, small intestine villus height and faecal volatile fatty acids in broilers. Br Poult Sci. 2009;50:298-306.

29. Kareem KY, Loh TC, Foo HL, Akit H, Samsudin AA. Effects of dietary postbiotic and inulin on growth performance, IGF1 and GHR mRNA expression, faecal microbiota and volatile fatty acids in broilers. BMC Vet Res. 2016;12:8-17.

30. Thu TV, Loh TC, Foo HL, Yaakub H, Bejo MH. Effects of liquid metabolite combinations produced by Lactobacillus plantarum on growth performance, faeces characteristics, intestinal morphology and diarrhoea incidence in postweaning piglets. Trop Anim Health Prod. 2011;43:69-75.

31. Izuddin WI, Loh TC, Samsudin AA, Foo HL, Humam AM, Shazali N. Effects of postbiotic supplementation on growth performance, ruminal fermentation and microbial profile, blood metabolite and GHR, IGF-1 and MCT-1 gene expression in post-weaning lambs. BMC Vet Res BMC Veterinary Research. 2019:15:1-10.

32. Van ThuT, Foo HL, Loh TC, Bejo MH. Inhibitory activity and organic acid concentrations of metabolite combinations produced by various strains of Lactobacillus plantarum. African J Biotechnol. 2011;10:1359-63.

33. Choe DW, Foo HL, Loh T, Bejo MH. Inhibitory property of metabolite combinations produced from lactobacillus plantarum strains. Pertanika J Trop Agric Sci. 2013;36:79-88.

34. Moghadam MS, Foo HL, Leow TC, Rahim RA, Loh TC. Novel bacteriocinogenic Lactobacillus plantarum strains and their differentiation by sequence analysis of 16S rDNA, 16S-23S and 23S-5S intergenic spacer regions and randomly amplified polymorphic DNA analysis. Food Technol Biotechnol. 2010;48:476-83.

35. Tai HF, Foo HL, Rahim RA, Loh TC, Abdullah MP, Yoshinobu K. Molecular characterisation of new organisation of plnEF and plw loci of bacteriocin genes harbour concomitantly in Lactobacillus plantarum I-UL4. Microb Cell Fact BioMed Central. 2015;14:1-13.
36. Chuah LO, Foo HL, Loh TC, Mohammed Alitheen NB, Yeap SK, Abdul Mutalib NE, et al. Postbiotic metabolites produced by Lactobacillus plantarum strains exert selective cytotoxicity effects on cancer cells. BMC Complement Altern Med. 2019;19:1-12.

37. Stackebrandt E, Ebers J. Taxonomic parameters revisited: Tarnished gold standards. Microbiol Today. 2006;8:6-9.

38. Patil S, Sawant S, Hauff K, Hampp G. Validated postbiotic screening confirms presence of physiologically-active metabolites, such as shortchain fatty acids, amino acids and vitamins in Hylak ${ }^{\circledR}$ Forte. Probiotics Antimicrob Proteins. 2019;11:1124-31.

39. Tenaillon O, Skurnik D, Picard B, Denamur E. The population genetics of commensal Escherichia coli. Nat Rev Microbiol. 2010:8:207-17.

40. Hudault S, Guignot J, Servin AL. Escherichia coli strains colonising the gastrointestinal tract protect germfree mice against Salmonella typhimurium infection. Gut. 2001;49:47-55.

41. Nzakizwanayo J, Dedi C, Standen G, Macfarlane WM, Patel BA, Jones BV. Escherichia coli Nissle 1917 enhances bioavailability of serotonin in gut tissues through modulation of synthesis and clearance. Sci Rep. 2015;5:1-13.

42. Nataro JP, Kaper JB. Diarrheagenic Escherichia coli. Clin Microbiol Rev. 1998;11:142-201.

43. Wanke CA. To know Escherichia coli is to know bacterial diarrheal disease. Clin Infect Dis. 2001;32:1710-2.

44. Lynn WA, Golenbock DT. Lipopolysaccharide antagonists. Immunol Today. 1992;13:271-6.

45. Steimle A, Autenrieth IB, Frick JS. Structure and function: Lipid A modifications in commensals and pathogens. Int J Med Microbiol. 2016;306:290-301.

46 Opiyo SO, Pardy RL, Moriyama H, Moriyama EN. Evolution of the Kdo2lipid A biosynthesis in bacteria. BMC Evol Biol. 2010;10:98.

47. Barth S, Duncker S, Hempe J, Breves G, Baljer G, Bauerfeind R. Escherichia coli Nissle 1917 for probiotic use in piglets: Evidence for intestinal colonization. J Appl Microbiol. 2009;107:1697-710.

48. Collins RF, Kargas V, Clarke BR, Siebert CA, Clare DK, Bond PJ, et al. Full-length, Oligomeric Structure of Wzz Determined by Cryoelectron Microscopy Reveals Insights into Membrane-Bound States. Structure. 2017;25(806-815):e3.

49. Roncero C, Casadaban MJ. Genetic analysis of the genes involved in synthesis of the lipopolysaccharide core in Escherichia coli K-12: three operons in the rfa locus. J Bacteriol. 1992;174:3250-60.

50. Blum G, Hacker J, Marre R. Properties of Escherichia coli strains of serotype O6. Infection. 1995;23:234-6.

51. Schulze J, Sonnenborn U. Re.: Oral administration of a certain strain of live Escherichia coli for intestinal disorders? (Infection 23 [1995] 51-54). Infection. 1995;23:184-6.

52. Grozdanov L, Zähringer U, Blum-Oehler G, Brade L, Henne A, Knirel YA, et al. A single nucleotide exchange in the wzy gene is responsible for the semirough $O 6$ lipopolysaccharide phenotype and serum sensitivity of Escherichia coli strain Nissle 1917. J Bacteriol. 2002;184:5912-25.

53. Tauschek M, Strugnell RA, Robins-Browne RM. Characterization and evidence of mobilization of the LEE pathogenicity island of rabbitspecific strains of enteropathogenic Escherichia coli. Mol Microbiol. 2002:44:1533-50

54. Scheppach W, Bartram HP, Richter F. Role of short-chain fatty acids in the prevention of colorectal cancer. Eur J Cancer. 1995;31:1077-80.

55. Salimi V, Shahsavari Z, Safizadeh B, Hosseini A, Khademian N, TavakoliYaraki M. Sodium butyrate promotes apoptosis in breast cancer cells through reactive oxygen species (ROS) formation and mitochondrial impairment. Lipids Health Dis. 2017;16:1-11.

56. Abe K. Butyric acid induces apoptosis in both human monocytes and lymphocytes equivalently. J Oral Sci. 2012;54:7-14.

57. Hinnebusch BF, Meng S, Wu JT, Archer SY, Hodin RA. The effects of shortchain fatty acids on human colon cancer cell phenotype are associated with histone hyperacetylation. J Nutr. 2002;132:1012-7.

58. Narayanan A, Baskaran SA, Amalaradjou MAR, Venkitanarayanan K. Anticarcinogenic properties of medium chain fatty acids on human colorectal, skin and breast cancer cells in vitro. Int J Mol Sci. 2015;16:5014-27.

59. Zídek Z, Kmoníčková E, Kostecká P, Tlaskalová-Hogenová H. Decisive role of lipopolysaccharide in activating nitric oxide and cytokine production by the probiotic Escherichia coli strain nissle 1917. Folia Microbiol (Praha). 2010:55:181-9. 
60 Halnes I, Baines KJ, Berthon BS, MacDonald-Wicks LK, Gibson PG, Wood LG. Soluble fibre meal challenge reduces airway inflammation and expression of GPR43 and GPR41 in asthma. Nutrients. 2017;9:89.

61. Vinolo MAR, Rodrigues HG, Hatanaka E, Sato FT, Sampaio SC, Curi R. Suppressive effect of short-chain fatty acids on production of proinflammatory mediators by neutrophils. J Nutr Biochem. 2011;22:849-55.

62. Ni YF, Wang J, Yan XL, Tian F, Zhao JB, Wang YJ, et al. Histone deacetylase inhibitor, butyrate, attenuates lipopolysaccharide-induced acute lung injury in mice. Respir Res. 2010;11:1-8.

63. Ohira H, Fujioka Y, Katagiri C, Mamoto R, Aoyama-Ishikawa M, Amako $K$, et al. Butyrate attenuates inflammation and lipolysis generated by the interaction of adipocytes and macrophages. J Atheroscler Thromb. 2013;20:425-42

64. Aoyama M, Kotani J, Usami M. Butyrate and propionate induced activated or non-activated neutrophil apoptosis via HDAC inhibitor activity but without activating GPR-41/GPR-43 pathways. Nutrition. 2010;26:653-61.
65. Vinolo MAR, Rodrigues HG, Nachbar RT, Curi R. Regulation of inflammation by short chain fatty acids. Nutrients. 2011;3:858-76.

66. Kim H, Kwon J, Choi SY, Ahn YG. Method development for the quantitative determination of short chain fatty acids in microbial samples by solid phase extraction and gas chromatography with flame ionization detection. J Anal Sci Technol. 2019;10:28.

\section{Publisher's Note}

Springer Nature remains neutral with regard to jurisdictional claims in published maps and institutional affiliations.
Ready to submit your research? Choose BMC and benefit from:

- fast, convenient online submission

- thorough peer review by experienced researchers in your field

- rapid publication on acceptance

- support for research data, including large and complex data types

- gold Open Access which fosters wider collaboration and increased citations

- maximum visibility for your research: over $100 \mathrm{M}$ website views per year

At BMC, research is always in progress.

Learn more biomedcentral.com/submissions 